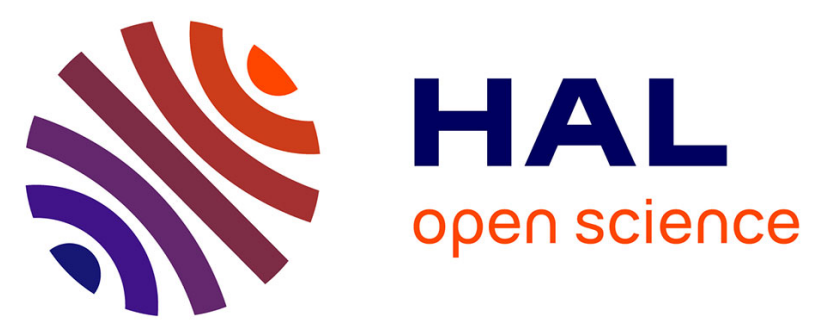

\title{
Synthesis of PDMS- b -POEGMA Diblock Copolymers and Their Application for the Thermoresponsive Stabilization of Water-Supercritical Carbon Dioxide Emulsions
}

Pierre Legout, Guillaume Lefebvre, Marie Bonnin, Jean-Christophe Gimel, Lazhar Benyahia, Olivier Colombani, Brice Calvignac

\section{To cite this version:}

Pierre Legout, Guillaume Lefebvre, Marie Bonnin, Jean-Christophe Gimel, Lazhar Benyahia, et al.. Synthesis of PDMS- b -POEGMA Diblock Copolymers and Their Application for the Thermoresponsive Stabilization of Water-Supercritical Carbon Dioxide Emulsions. Langmuir, 2020, 36, pp.1292212932. 10.1021/acs.langmuir.0c02194 . hal-02973293

\section{HAL Id: hal-02973293 \\ https://univ-angers.hal.science/hal-02973293}

Submitted on 22 Oct 2020

HAL is a multi-disciplinary open access archive for the deposit and dissemination of scientific research documents, whether they are published or not. The documents may come from teaching and research institutions in France or abroad, or from public or private research centers.
L'archive ouverte pluridisciplinaire HAL, est destinée au dépôt et à la diffusion de documents scientifiques de niveau recherche, publiés ou non, émanant des établissements d'enseignement et de recherche français ou étrangers, des laboratoires publics ou privés. 


\title{
Synthesis of PDMS- $b$-POEGMA diblock copolymers and their application for the thermo-responsive stabilization of water- supercritical carbon dioxide emulsions
}

\author{
Pierre Legout ${ }^{1,2}$, Guillaume Lefebvre ${ }^{1}$, Marie Bonnin ${ }^{1}$, Jean-Christophe Gimel ${ }^{1}$, Lazhar Benyahia ${ }^{2}$, Olivier \\ Colombani $^{2, *}$ and Brice Calvignac ${ }^{1, *}$ \\ Published in Langmuir : https://dx.doi.org/10.1021/acs.langmuir.0c02194, \\ ${ }^{1}$ Micro et Nanomédecines Translationnelles, MINT, UNIV Angers, UMR INSERM 1066, UMR CNRS 6021, \\ Angers. ${ }^{2}$ Institut des Molécules et Matériaux du Mans (IMMM), UMR 6283 CNRS Le Mans Université, Avenue \\ Olivier Messiaen, 72085 Le Mans Cedex 9, France.
}

KEYWORDS. supercritical carbon dioxide, emulsion, amphiphilic block copolymer, surfactant, poly(dimethyl siloxane), poly(ethylene glycol methacrylate), interfacial tension, stimuli-responsive.

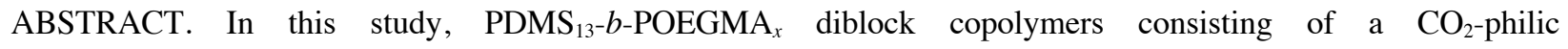
poly(dimethylsiloxane) (PDMS) block connected to a thermosensitive hydrophilic poly(oligoethylene glycol methacrylate) (POEGMA) block, were synthetized by reversible addition-fragmentation chain-transfer (RAFT) radical polymerization. Their ability to decrease the water-supercritical $\mathrm{CO}_{2}\left(\mathrm{scCO}_{2}\right)$ interfacial tension $(\gamma)$ and to stabilize water- $\mathrm{scCO}_{2}$ emulsions was investigated using an original home-made device developed in the laboratory. This device is able to control the pressure from 1 to 250 bar and the temperature from 40 to $80^{\circ} \mathrm{C}$. It was implemented with 2 visualization windows, a drop tensiometer and a remote optical head for dynamic light scattering (DLS) measurements. These experiments revealed that PDMS- $b$-POEGMA decreased $\gamma$ down to $1-2 \mathrm{mN} / \mathrm{m}$ and was the most efficient at high pressure $\left(250\right.$ bar) and low temperature $\left(40^{\circ} \mathrm{C}\right)$ where PDMS and POEGMA blocks exhibited the highest affinity for their respective phase. The diblock copolymers were shown to stabilize water-scCO $\mathrm{emulsions}_{2}$ Moreover, the thermosensitive behavior of the POEGMA block in water (with a lower critical solubility temperature around $65^{\circ} \mathrm{C}$ ) resulted in the formation of temperature-responsive emulsions that could reversibly switch at 100 bar from stable at $40^{\circ} \mathrm{C}$ to unstable at $80^{\circ} \mathrm{C}$. These results were rationalized based on the solubility of each individual block of the copolymers in water and $\mathrm{scCO}_{2}$ as a function of temperature and pressure. 


\section{Introduction}

Supercritical carbon dioxide $\left(\mathrm{scCO}_{2}\right)$, due to its unique properties (e.g., nontoxicity, nonflammability, moderate critical temperature and pressure) is increasingly considered for various industrial applications (e.g. extraction, foaming, chemical reaction, dry cleaning). ${ }^{1}$ Over the last 20 years, a special focus was set on the production of water-in- $\mathrm{scCO}_{2}$ $(\mathrm{W} / \mathrm{C})$ or $\mathrm{scCO}_{2}$-in-water $(\mathrm{C} / \mathrm{W})$ emulsions and microemulsions ${ }^{2}$ as they can act as "universal solvents" by dissolving simultaneously polar, ionic and nonpolar molecules. These dispersed systems have numerous fields of application, including chemical processing, solubilization and separation, synthesis of polymer colloids or inorganic particles. ${ }^{3,4,5,6}$ The stabilization of $\mathrm{C} / \mathrm{W}$ or $\mathrm{W} / \mathrm{C}$ emulsions can be achieved with molecular surfactants $^{7-10}$ or amphiphilic block ${ }^{2,11,12}$ copolymers which lower the water-sc $\mathrm{CO}_{2}$ interfacial tension $(\gamma)$ and sterically and/or electrostatically hinder the coalescence of water or $\mathrm{scCO}_{2}$ droplets. ${ }^{13}$ Alternatively, solid particles can also lead to very stable water- $\mathrm{scCO}_{2}$ emulsions $^{5,14}$ through the Pickering effect. ${ }^{15,16}$

$\mathrm{CO}_{2}$-philic copolymers used to stabilize water-sc $\mathrm{CO}_{2}$ emulsions were extensively reviewed by Girard et al., ${ }^{2}$ focusing on their interactions with $\mathrm{CO}_{2}$. Among the different polymers reviewed, those exhibiting the highest affinity for $\mathrm{CO}_{2}$ are poly(vinyl acetate) < poly(dimethyl siloxanes) (PDMS) < poly(fluoroalkyl acrylates), in this order. ${ }^{17}$ Moreover, shorter polymers have a higher solubility in $\mathrm{scCO}_{2}$ for entropic reasons. ${ }^{18}$ Only few studies were devoted to PDMS-based amphiphilic copolymers and their use as emulsifiers. Indeed, the strong affinity of PDMS for $\mathrm{CO}_{2}$ suggests that amphiphilic PDMS-based copolymers should strongly reduce $\gamma$ and successfully stabilize $\mathrm{W} / \mathrm{C}$ or $\mathrm{C} / \mathrm{W}$ emulsions. Amphiphilic copolymers with a rather short
PDMS block (from 1,000 to $10,000 \mathrm{~g} / \mathrm{mol}$ ) were connected to either a poly(2-hydroxymethacrylate) (PHEMA) block, ${ }^{19}$ poly(ethylene oxide) (PEO) grafts, ${ }^{11}$ or a $\mathrm{pH}$-sensitive poly(acrylic acid) (PAA) ${ }^{12}$ block. These three polymer families were shown to stabilize W-C emulsions. PEO- $b$-PDMS- $b$-PEO triblocks were used to prepare $\mathrm{W}-\mathrm{C}$ miniemulsions.$^{20}$ No attempts were made to correlate the polymer chemical structure with its ability to reduce $\gamma$ or to stabilize emulsions.

To characterize the affinity of molecular surfactants or block copolymers with both the water and $\mathrm{CO}_{2}$ phases, the hydrophilic $\mathrm{CO}_{2}$-philic balance ( $\left.\mathrm{HCB}\right)$ parameter has been proposed in the literature (Eq. 1). ${ }^{11}$

$$
H C B=\frac{A_{\mathrm{HW}}-A_{\mathrm{HH}}-A_{\mathrm{WW}}}{A_{\mathrm{TC}}-A_{\mathrm{TT}}-A_{\mathrm{CC}}} \quad \text { Equation } 1
$$

With $A$ the cohesive energies between the different chemical species denoted by subscripts: $\mathrm{T}$ for the $\mathrm{CO}_{2-}$ philic part of the amphiphilic molecule, $\mathrm{H}$ for its hydrophilic part, $\mathrm{W}$ for water and $\mathrm{C}$ for $\mathrm{CO}_{2}$.

The HCB originates from the hydrophilic lipophilic balance (HLB) which characterizes a surfactant used in a water-oil system. ${ }^{5,21}$ However, unlike the HLB, which is only based on the surfactant chemical structure, the theoretical HCB calculation takes into account all cohesive energies involved and thus all interactions of the surfactant molecule with its environment under specific conditions (e.g. temperature, pressure, salinity). With these considerations, the HCB calculation relates more closely to the extended version of the Winsor R ratio ${ }^{22}$ or to the hydrophilic lipophilic difference (HLD) calculation produced by Salager, ${ }^{23,24}$ both developed for water-oil systems. Due to the difficulty to determine the cohesive energy values in equation 1, the HCB is mainly used as a qualitative concept to assess the influence of all involved interactions in the presence of a surfactant at a water- $\mathrm{CO}_{2}$ interface (Figure 1) (we only found one exception where the HCB was calcula to Figure 
1, when the HCB value is more than one (respectively less than one), the amphiphilic molecule or copolymer is considered as predominantly hydrophilic (respectively $\mathrm{CO}_{2}$-philic) and leads preferentially to the formation of $\mathrm{C} / \mathrm{W}$ (respectively $\mathrm{W} / \mathrm{C}$ ) emulsions in accordance to the Bancroft's rule. ${ }^{5,26}$ When the HCB reaches a value close to one, the amphiphilic molecule or copolymer shows a balanced state with equal affinities for water and $\mathrm{CO}_{2}$, leading to a minimum $\gamma$.

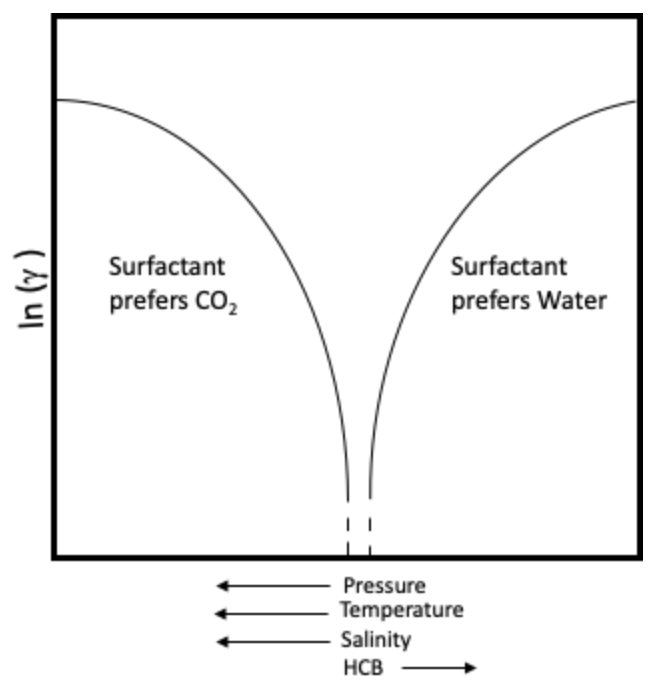

Figure 1. Schematic representation of the effect of various formulation parameters on $\ln (\gamma)$ for a nonionic surfactant at the water- $\mathrm{CO}_{2}$ interface.

In this study, a small PDMS $\left(\mathrm{DP}_{\mathrm{n}}=13\right)$ was chosen as the $\mathrm{CO}_{2}$-philic block and a thermo-responsive poly(oligo(ethylene glycol) methacrylate) (POEGMA $)$ with three different number-average degrees of polymerization $\left(\mathrm{DP}_{\mathrm{n}}=x=16,31\right.$ and 46$)$ was chosen as the hydrophilic block. POEGMA exhibits a lower critical solution temperature (LCST) in water of $65^{\circ} \mathrm{C}$ (at normal pressure $P=1 \mathrm{~atm}$ and for OEGMA monomer units consisting of 4-5 ethylene glycol units, with molar mass $\left.\mathrm{M}_{\mathrm{OEGMA}}=300 \mathrm{~g} / \mathrm{mol}\right) .{ }^{27}$ The synthesis of PDMS- $b$-POEGMA by combination of anionic ring opening polymerization and atom transfer radical polymerization (ATRP) has already been reported, ${ }^{28}$ but the interfacial behavior of these polymers or their ability to stabilize emulsions have never been studied. Here, three $\mathrm{PDMS}_{13}-b$-POEGMA $x$ diblock copolymers were synthesized by reversible addition-fragmentation chain transfer (RAFT) radical polymerization of OEGMA from a $\mathrm{PDMS}_{13}$-based chain transfer agent $\left(\mathrm{PDMS}_{13^{-}}\right.$ CTA). The reduction of $\gamma$ was measured as a function of the copolymer concentration, temperature, pressure, andthe POEGMA block length. Moreover, the ability of the diblock copolymers to stabilize water- $\mathrm{scCO}_{2}$ emulsions in different conditions of temperature and pressure was investigated. This could be achieved using a home-made device including a pendant-drop tensiometer and visualization windows enabling both direct visual observations and in situ dynamic light scattering (DLS) measurements. The ability of the polymers to stabilize or not water- $\mathrm{ScCO}_{2}$ emulsions depending on $\mathrm{T}$ and $\mathrm{P}$ was also discussed regarding thei efficiency to reduce $\gamma$ and the solubility of both blocks in $\mathrm{scCO}_{2}$ and water.

\section{Experimental section}

\section{Materials}

Pure water (milliQ, $18 \mathrm{M} \Omega . \mathrm{cm}$ ), $\mathrm{CO}_{2}$ (Linde, $100 \%$ ), pentane (Aldrich, $99 \%$ ), diethyl ether (Aldrich, $99 \%$ ), sodium chloride (Aldrich, $99 \%$ ), sodium bicarbonate (Aldrich), $\mathrm{MgSO}_{4}$, C-hydroxy functional PDMS (PDMS-OH Monocarbinol Terminated Polydimethylsiloxane, CAS : 207308-30-3, Figure 3, $\mathrm{M}_{\mathrm{n}}=1180 \mathrm{~g} / \mathrm{mol}, \quad \mathrm{DP}_{\mathrm{n}}=13, \quad$ Gelest MCR-C12), dimethylaminopyridine (DMAP, Acros), N,N'dicyclohexylcarbodiimide (DCC, Aldrich), triethylamine (Aldrich, 99.5\%), toluene (Aldrich, $99 \%$ ), methanol (Aldrich, 99\%), 4-cyano-4(phenylcarbonothioylthio) pentanoic acid (CTA$\mathrm{COOH}$, Aldrich, $99 \%$ ), tetrahydrofuran (THF, 
Aldrich), dichloromethane $\left(\mathrm{CH}_{2} \mathrm{Cl}_{2}\right.$, Aldrich) and acetonitrile (Aldrich, $99 \%$ ) were used as received. AIBN (Aldrich, 98\%) was recrystallized from methanol and OEGMA $300 \mathrm{~g} / \mathrm{mol}$ (Aldrich) was purified on a basic alumina column before use to remove inhibitor.

\section{Characterization techniques}

\section{Nuclear magnetic resonance spectroscopy}

Nuclear Magnetic Resonance (NMR) spectra were recorded using deuterated chloroform $\left(\mathrm{CDCl}_{3}\right)$ on a BRUKER advance DPX spectrometer operating at $400 \mathrm{MHz}$ for ${ }^{1} \mathrm{H}$ NMR. Coupling constants (J) are denoted in $\mathrm{Hz}$ and chemical shifts $(\delta)$ in parts per million (ppm) relative to tetramethylsilane (TMS).

\section{Size Exclusion Chromatography}

Size exclusion chromatography (SEC) was performed using a system made of a guard column ( $5 \mu \mathrm{m}$ beads, $50 \times 7.5 \mathrm{~mm}$ ) connected to a PLgel Mixed-D column ( $5 \mu \mathrm{m}$ beads with a distribution of pore sizes from $50 \AA$ to a few $\mu \mathrm{m}, 300 \times 7.5 \mathrm{~mm}$ ) and a PLgel column ( $5 \mu \mathrm{m}$ beads with individual pore sizes of $50 \AA, \quad 300 \times 7.5 \mathrm{~mm})$. Online light scattering (miniDAWN TREOS from Wyatt, equipped with a $120 \mathrm{~mW}$ laser with $\lambda=656 \mathrm{~nm}$ ), refractive index (RID10A from Shimadzu) and UV (Spectra Physics Analitical UV1000, $254 \mathrm{~nm}$ ) were used for detection. All samples were analyzed in THF at room temperature using a $1 \mathrm{~mL} / \mathrm{min}$ flow rate with a Prominence HPLC system (Shimadzu). After filtration (0.2 $\mu \mathrm{m}$ syringe filters, Acrodisc), $100 \mu \mathrm{L}$ of $2 \mathrm{~g} / \mathrm{L}$ polymer solutions were injected. Number-average $\left(M_{n}\right)$ and weightaverage $\left(M_{w}\right)$ molar masses and dispersity $\left(Đ=M_{w} / M_{n}\right)$ were calculated by light scattering, using the refractive index detector for concentration calculations knowing the specific refractive index increment $\mathrm{dn} / \mathrm{dc}$ of the polymers. The dn/dc of the copolymers in THF was determined at $20^{\circ} \mathrm{C}$ using a Spectra System P100
(Wyatt) differential refractometer operating at $\lambda=633 \mathrm{~nm}$. Solutions with various concentrations $(1,2$, 3,4 and $5 \mathrm{~g} / \mathrm{L}$ ) were successively injected, leading to $\mathrm{dn} / \mathrm{dc}=0.06 \pm 0.01 \mathrm{~mL} / \mathrm{g}$ for the three diblock polymers. The residual molar fractions of PDMS-CTA in the unpurified PDMS $_{13}-b$-POEGMA ${ }_{x}$ diblock copolymers were determined by UV absorption at $254 \mathrm{~nm}$. Molar extinction coefficients at this wavelength were determined by UV/Vis spectroscopy in THF with a Varian Cary-50 Bio UV-Visible spectrometer (Les Ulis, France) by measuring 5 solutions from 0.06 to $0.15 \mathrm{mg} / \mathrm{L}$, leading to $\varepsilon=2.8 \mathrm{~L} / \mathrm{mol} / \mathrm{cm}$ for PDMS $_{13}-\mathrm{CTA}$ and $\varepsilon=1.9 \mathrm{~L} / \mathrm{mol} / \mathrm{cm}$ for the three $\mathrm{PDMS}_{13}-b-\mathrm{POEGMA}_{x}$ independent of $x$ (see SI for details, section 2 and Figure S2).

\section{Synthesis}

Synthesis of PDMS ${ }_{13}-C T A$

4-(dimethylamino)pyridine $\quad(0.12 \mathrm{~g}, \quad 0.1 \mathrm{mmol}$, $0.15 \mathrm{eq})$, PDMS-OH (7.5 g, $6.8 \mathrm{mmol}, 1 \mathrm{eq}), \mathrm{CH}_{2} \mathrm{Cl}_{2}$ dry (30 g) and 4-(cyano-dithiobenzoate) pentanoic acid ( $2.9 \mathrm{~g}, 10 \mathrm{mmol}, 1.5 \mathrm{eq})$ were added in a $100 \mathrm{~mL}$ roundbottom flask equipped with a stir bar and an addition funnel. The solution was stirred and degassed with argon for 10 minutes. DCC (2.1 g, $10 \mathrm{mmol}, 1.5 \mathrm{eq})$ was dissolved in dry $\mathrm{CH}_{2} \mathrm{Cl}_{2}(8 \mathrm{~g})$ and added dropwise to the reaction flask at $0^{\circ} \mathrm{C}$. Then, the reaction medium was stirred at room temperature overnight. The solid was removed by filtration, and the filtrate was washed once with an aqueous solution of sodium bicarbonate $(20 \mathrm{~mL}$, $10 \% \mathrm{w} / \mathrm{w})$ and twice with pure water $(2 \times 20 \mathrm{~mL})$. The filtrate was then dried with anhydrous $\mathrm{MgSO}_{4}$ and concentrated on a rotary evaporator before precipitation of the polymer in a water/methanol mixture (20/80 v/v). A liquid pinkish polymer was finally obtained (6.2 g, yield $=65 \%$ ). 
${ }^{l} \mathrm{H} \mathrm{NMR}\left(\mathrm{CDCl}_{3}\right) \mathrm{ppm}: 0.1\left(\mathrm{~m}, 82 \mathrm{H}=6 \times \mathrm{DP}_{\mathrm{n}}+6\right.$ corresponding to $\left.\mathrm{DP}_{\mathrm{n}}=13, \mathrm{CH}_{3}-\mathrm{Si}_{-}-\mathrm{CH}_{3}\right) ; 0.5(\mathrm{~m}, 4 \mathrm{H}$, $\mathrm{CH}_{2}-\mathrm{Si}$ ); 0.82 (t, $\left.3 \mathrm{H}, \mathrm{CH}_{3}-\mathrm{CH}_{2}-\mathrm{CH}_{2}-\mathrm{CH}_{2}-\mathrm{Si}-\right) ; 1.30$ (m, $\left.4 \mathrm{H},-\mathrm{CH}_{2}-\mathrm{CH}_{2}-\mathrm{Si}-\right) ; 1.73\left(\mathrm{~m}, 2 \mathrm{H}, \mathrm{CH}_{3}-\mathrm{CH}_{2}-\mathrm{CH}_{2}-\mathrm{CH}_{2}-\right.$ $\mathrm{Si}$ ); 1.95 (s, 3H, $\left.\mathrm{CH}_{3}-\mathrm{C}(\mathrm{CN})-\right)$; 2.38-2.80 (m, 4H, $\left.(\mathrm{C}=\mathrm{O})-\mathrm{CH}_{2}-\mathrm{CH}_{2}-\mathrm{C}-\right)$; 3.45 (t, $2 \mathrm{H},-\mathrm{CH}_{2}-\mathrm{O}-\mathrm{CH}_{2}-\mathrm{CH}_{2}-\mathrm{O}-$ $(\mathrm{C}=\mathrm{O})-) ; 3.66$ (t, $\left.2 \mathrm{H},-\mathrm{CH}_{2}-\mathrm{O}-\mathrm{CH}_{2}-\mathrm{CH}_{2}-\mathrm{O}-(\mathrm{C}=\mathrm{O})-\right)$; 4.29 (t, $\left.2 \mathrm{H},-\mathrm{CH}_{2}-\mathrm{O}-\mathrm{CH}_{2}-\mathrm{CH}_{2}-\mathrm{O}-(\mathrm{C}=\mathrm{O})-\right) ; 7.42(\mathrm{dt}, 2 \mathrm{H}$, $\left.{ }^{3} \mathrm{~J}(\mathrm{H}, \mathrm{H})=8.4 \mathrm{~Hz},{ }^{3} \mathrm{~J}(\mathrm{H}, \mathrm{H})=7.6 \mathrm{~Hz}, \mathrm{~m}-\mathrm{ArH}\right) ; 7.56(\mathrm{dt}$, $\left.1 \mathrm{H},{ }^{3} \mathrm{~J}(\mathrm{H}, \mathrm{H})=7.6 \mathrm{~Hz},{ }^{4} \mathrm{~J}(\mathrm{H}, \mathrm{H})=1.2 \mathrm{~Hz}, \mathrm{p}-\mathrm{ArH}\right) ; 7.9(\mathrm{dt}$, $\left.2 \mathrm{H},{ }^{3} \mathrm{~J}(\mathrm{H}, \mathrm{H})=8.4 \mathrm{~Hz},{ }^{4} \mathrm{~J}(\mathrm{H}, \mathrm{H})=1.2 \mathrm{~Hz}, \mathrm{o}-\mathrm{ArH}\right)$.

\section{Synthesis of PDMS $S_{13}-b-P O E G M A_{x}$}

In a typical run corresponding to $\mathrm{PDMS}_{13}-b$ POEGMA $_{46}$, OEGMA (20 g, $\left.66.7 \mathrm{mmol}, 40 \mathrm{eq}\right)$, AIBN initiator (0.05 g, $3.3 \mathrm{mmol}, 0.2 \mathrm{eq})$, PDMS-CTA ( $\mathrm{g}$, $1.6 \mathrm{mmol}, 1 \mathrm{eq})$ and $20 \mathrm{~g}$ of toluene were added in a Schlenk flask. Five freeze-pump-thaw-argon cycles were carried out to remove oxygen. Then, the reaction medium was heated in an oil bath at $70^{\circ} \mathrm{C}$. To monitor polymerization kinetics, aliquots were regularly collected under argon and analyzed by ${ }^{1} \mathrm{H}$ NMR (monomer conversion) and $\operatorname{SEC}\left(\mathrm{M}_{\mathrm{n}}, \mathrm{Ð}\right)$. The overall monomer conversion was determined by ${ }^{1} \mathrm{H}$ NMR spectroscopy in DMSO- $\mathrm{d}_{6}$ by the relative integration of the protons of the polymer at $4.1 \mathrm{ppm}$ and the vinylic protons of the monomer at 5.6 and $6.1 \mathrm{ppm}$. The kinetic plots allowed determining the time required to reach the desired conversion. At this time, the reaction was stopped by cooling the reaction medium in an ice bath and opening it to air. The final conversion was confirmed by ${ }^{1} \mathrm{H}$ NMR. To purify the copolymer, it was precipitated in a mixture of $80 \%$ pentane and $20 \%$ diethyl ether (by volume). A viscous pinkish copolymer was finally obtained $(7.5 \mathrm{~g}$, yield $=63 \%)$.
${ }^{1} \mathrm{H} \mathrm{NMR}\left(\mathrm{CDCl}_{3}\right)$ ppm for $\mathrm{PDMS}_{13}-b$-POEGMA 46 : $0.1\left(\mathrm{~m}, 82 \mathrm{H}=6 \times \mathrm{DP}_{\mathrm{n}}(\mathrm{PDMS})+6\right.$ corresponding to $\left.\mathrm{DP}_{\mathrm{n}}(\mathrm{PDMS})=13, \mathrm{CH}_{3}-\mathrm{Si}-\mathrm{CH}_{3}\right) ; 0.5\left(\mathrm{~m}, 4 \mathrm{H},-\mathrm{CH}_{2}-\mathrm{Si}\right)$; 0.6-2.8 ( $\sim 286 \mathrm{H}$ corresponding to the following protons: $\sim 0.8 \mathrm{ppm}, \mathrm{t}, 3 \mathrm{H}, \mathrm{CH}_{3}-\mathrm{CH}_{2}-\mathrm{CH}_{2}-\mathrm{CH}_{2}-\mathrm{Si}-; \sim 1 \mathrm{ppm}, \mathrm{s}$, $3 \mathrm{H} \times \mathrm{DP}_{\mathrm{n}}(\mathrm{POEGMA}),-\mathrm{CH}_{2}-\mathrm{C}\left(\mathrm{CH}_{3}\right)-\mathrm{C}=\mathrm{O} ; \sim 1.3 \mathrm{ppm}$, $\mathrm{m}, 4 \mathrm{H},-\mathrm{CH}_{2}-\mathrm{CH}_{2}-\mathrm{Si}-; \sim 1.7 \mathrm{ppm}, \mathrm{m}, 2 \mathrm{H}, \mathrm{CH}_{3}-\mathrm{CH}_{2}-\mathrm{CH}_{2}-$ $\mathrm{CH}_{2}-\mathrm{Si}-; \sim 1.8 \mathrm{ppm}, \mathrm{m}, 2 \mathrm{H} \times \mathrm{DP}_{\mathrm{n}}(\mathrm{POEGMA}),-\mathrm{CH}_{2^{-}}$ $\left.\mathrm{C}\left(\mathrm{CH}_{3}\right)-\mathrm{C}=\mathrm{O} ; 2.3 \mathrm{pm}, \mathrm{s}, 3 \mathrm{H}, \mathrm{CH}_{3}-\mathrm{C}(\mathrm{CN})-\right) ; 2.4-2.8, \mathrm{~m}$, $\left.\left.4 \mathrm{H}, \quad-(\mathrm{C}=\mathrm{O})-\mathrm{CH}_{2}-\mathrm{CH}_{2}-\mathrm{C}-\right)\right) ; \quad 3.0-3.8 \quad(\sim 892 \quad \mathrm{H}$ corresponding to the following protons: $3.3, \mathrm{~s}, 3 \mathrm{H} \times \mathrm{DP}_{\mathrm{n}}$ POEGMA - $\left(\mathrm{CH}_{2}-\mathrm{CH}_{2}-\mathrm{O}\right)_{4-5}-\mathrm{CH}_{3} ; 3.45, \mathrm{t}, 2 \mathrm{H},-\mathrm{CH}_{2}$-O$\left.\mathrm{CH}_{2}-\mathrm{CH}_{2}-\mathrm{O}-(\mathrm{C}=\mathrm{O})-\right) ; 3.6, \mathrm{~m}, 16 \mathrm{H} \times \mathrm{DP}_{\mathrm{n}}(\mathrm{POEGMA})-$ $(\mathrm{C}=\mathrm{O})-\mathrm{CH}_{2}-\mathrm{CH}_{2}-\mathrm{O}-\left(\mathrm{CH}_{2}-\mathrm{CH}_{2}-\mathrm{O}\right)_{3-4}-\mathrm{CH}_{3} ; 3.66, \mathrm{t}, 2 \mathrm{H}$, $\left.\left.\mathrm{CH}_{2}-\mathrm{O}-\mathrm{CH}_{2}-\mathrm{CH}_{2}-\mathrm{O}-(\mathrm{C}=\mathrm{O})-\right)\right) ; \quad 4.1 \quad(92 \mathrm{H}, \quad \mathrm{m}$, $2 \mathrm{H} \times \mathrm{DP}_{\mathrm{n}}(\mathrm{POEGMA})$ corresponding to $\mathrm{DP}_{\mathrm{n}}(\mathrm{POEGMA})$ $\left.=46,-(\mathrm{C}=\mathrm{O})-\mathrm{CH}_{2}-\mathrm{CH}_{2}-\mathrm{O}-\left(\mathrm{CH}_{2}-\mathrm{CH}_{2}-\mathrm{O}\right)_{3-4}-\mathrm{CH}_{3}\right) ; 4.3$ $\left(\mathrm{m}, 2 \mathrm{H},-\mathrm{CH}_{2}-\mathrm{O}-\mathrm{CH}_{2}-\mathrm{CH}_{2}-\mathrm{O}-(\mathrm{C}=\mathrm{O})-\right) ; 7.42(\mathrm{~m}, 2 \mathrm{H}, \mathrm{m}-$ ArH); $7.56(\mathrm{~m}, 1 \mathrm{H}, \mathrm{p}-\mathrm{ArH}) ; 7.9\left(\mathrm{dt}, 2 \mathrm{H},{ }^{3} \mathrm{~J}(\mathrm{H}, \mathrm{H})=8.4\right.$ $\left.\mathrm{Hz},{ }^{4} \mathrm{~J}(\mathrm{H}, \mathrm{H})=1.2 \mathrm{~Hz}, 2 \mathrm{H}, \mathrm{o}-\mathrm{ArH}\right)$.

Size exclusion chromatography for $\mathrm{PDMS}_{13}-b-$ POEGMA $_{46}: \mathrm{M}_{\mathrm{n}}=16,000 \mathrm{~g} / \mathrm{mol}, \mathrm{D}=1.1$.

See Table 1 for the characteristics of the other polymers.

\section{Interfacial tension measurements}

The interfacial tension measurements were performed on a high pressure, high temperature homemade device (Figure 2) developed in partnership with Top Industrie and controlled by the Windrop ${ }^{\circledR}$ software (Teclis). This device was composed of a motorized and variable volume view cell (Top Industrie) for the $\mathrm{scCO}_{2}$ injection and a syringe pump (260D P2 ISCO, USA) for the injection of the aqueous solution containing the amphiphilic copolymer. This solution was injected in a $50 \mathrm{~mL}$ stirred measurement cell (Top Industrie) 
equipped with a light source. A video camera was mounted on an optical rail for proper alignment and connected to a computer for video acquisitions. The measurement cell initially contained a small amount of water (approx. $3 \mathrm{~mL}$ ), stirred to ensure the $\mathrm{CO}_{2}$ phase saturation. The $\mathrm{CO}_{2}$ was first injected to the desired pressure and the cell was thermalized between 40 and $80^{\circ} \mathrm{C}$ with a heated bath (Fisherbrand Isotemp 6200H7). Then, the aqueous polymer solution was introduced in the measurement cell with the syringe pump to obtain a $5 \mu \mathrm{L}$ pendant drop by setting a desired pressure (typically 3 to 5 bar above the pressure of the measurement cell to avoid backflow). Finally, the interfacial tension measurement between the aqueous solution and the water-saturated $\mathrm{CO}_{2}$ was started and maintained, keeping the volume of the droplet constant, until $\gamma$ remained stable for at least 2 minutes. The interfacial tension measurements were carried out by fitting the Laplace equation (Eq. 2) to the profile of the recorded pendant drop images, where $\Delta P$ is the pressure difference across the water- $\mathrm{CO}_{2}$ interface, $R_{0}$ is the radius of curvature at the apex of the drop, $H_{0}$ and $H_{1}$ are the principal radii of curvature and $z$ is the vertical distance..$^{29}$

$$
\Delta P=2 \gamma\left(\frac{1}{H_{O}}+\frac{1}{H_{1}}\right)=\Delta \rho g z+\frac{2 \gamma}{R_{0}}
$$

Equation 2

The interfacial tension measurements at different pressures and different temperatures were made with the same aqueous solution for each polymer and each concentration. However, for each measurement, a new droplet was formed after equilibration of $\mathrm{T}$ and $\mathrm{P}$ in the apparatus. After each measurement, a sufficient amount of aqueous solution was pushed into the droplet to detach it from the needle.

Table 1. Experimental conditions for the synthesis of the $\mathrm{PDMS}_{13}-b-\mathrm{POEGMA}_{x}$ diblock copolymers and characteristics of the final polymers

\begin{tabular}{cccccccc}
\hline$x^{\mathrm{a}}$ & $\begin{array}{c}{\text { OOEGMA }]_{0}:}^{[\text {PDMS- }} \\
\text { CTA }]_{0}:\end{array}$ & $\begin{array}{c}\text { OEGMA } \\
\text { conversion } \\
{[\text { AIBN }]_{0}{ }^{\mathrm{b}}}\end{array}$ & $\begin{array}{c}\text { CTA } \\
\text { efficiency } \\
(\%)^{\mathrm{c}}\end{array}$ & $\begin{array}{c}\mathrm{M}_{\mathrm{n} \text { theo }} \\
(\mathrm{g} / \mathrm{mol})^{\mathrm{d}}\end{array}$ & $\begin{array}{c}\mathrm{M}_{\mathrm{n} \text { exp }} \\
(\mathrm{g} / \mathrm{mol})^{\mathrm{e}}\end{array}$ & $\mathrm{Ð}^{\mathrm{e}}$ & $\begin{array}{r}\text { wt\% } \\
\text { POEGMA }\end{array}$ \\
\hline 16 & $20: 1: 0.2$ & 52 & 65 & 5000 & 7500 & 1.1 & 84 \\
31 & $40: 1: 0.2$ & 30 & 48 & 8000 & 12000 & 1.1 & 89 \\
46 & $40: 1: 0.2$ & 60 & 45 & 16000 & 17000 & 1.1 & 93 \\
\hline
\end{tabular}

\footnotetext{
a Determined by ${ }^{1} \mathrm{H}$ NMR on the purified polymer; ${ }^{b}$ Molar ratio of the reagents; ${ }^{\mathrm{c}}$ Determined from the relative areas of the peaks in SEC, see SI section 2; ${ }^{\mathrm{d}}$ Theoretical $\mathrm{M}_{\mathrm{n}}=\mathrm{M}_{\mathrm{PDMS}-\mathrm{CTA}}+[\mathrm{OEGMA}]_{0} \times$ conversion $\times \mathrm{M}_{\mathrm{OEGMA}} /\left(\mathrm{f} \times[\mathrm{PDMS}-\mathrm{CTA}]_{0}\right) ;{ }^{\mathrm{e}} \mathrm{M}_{\mathrm{n}}$ and $\oplus$ determined by SEC in THF using light scattering and refractive index detections.
} 


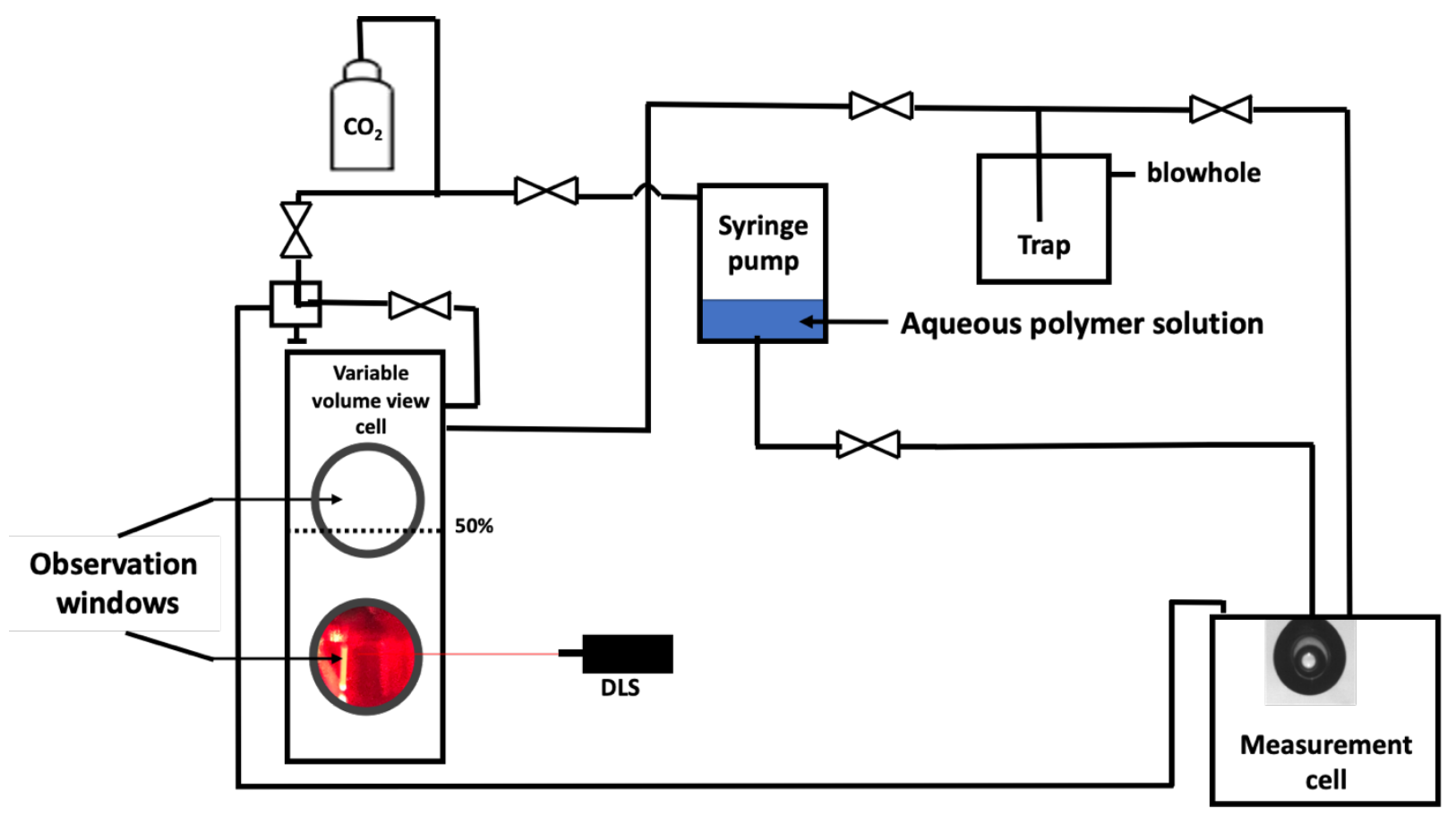

Figure 2. Schematic view of the home-made device used to measure both $\gamma$ in the measurement cell (on the right) or the stability of the emulsions in the variable volume view cell (on the left). In the latter, two windows allowed the macroscopic observation of the water- $\mathrm{scCO}_{2}$ mixture. Moreover, a deported DLS apparatus was installed on the bottom observation window for further measurements (see section 6 of the experimental section).

\section{Formation of water-carbon dioxide emulsions and} stability

Emulsions of water and $\mathrm{scCO}_{2}$ were prepared in the variable volume view cell of the home-made device (Figure 2). First, the studied copolymer was solubilized in deionized water and placed in the view cell. Then, $\mathrm{scCO}_{2}$ was injected to the desired volume fraction and the pressure was controlled with the syringe pump. The temperature of the apparatus was controlled with the heated bath. The copolymer/water/ $/ \mathrm{scO}_{2}$ mixture was emulsified with a $28 \mathrm{~mm}$ diameter four bladed propeller at $900 \mathrm{rpm}$ for $15 \mathrm{~min}$, resulting in the formation of a white and turbid emulsion (see Figure $8 \mathrm{~b}$ ). Then, the stirring was stopped, and the emulsions were characterized visually. DLS measurements were conducted on the aqueous bottom phase which appeared after creaming of the emulsion with a Cordouan ${ }^{\circledR}$ particle size analyzer (VASCO Kin) operating at a wavelength of $638 \mathrm{~nm}$ and a fixed scattering angle of $170^{\circ}$. The remote head of the apparatus was positioned at the bottom of the first window as depicted on Figure 2. Traces of the scattered light intensity and intensitytime correlation functions, $g_{2}(\Delta t)$, with $\Delta t$ the delay time, were recorded in the bottom phase before (aqueous polymer solution) and after creaming of the emulsion. As measurements were not performed on diluted systems in the limit of low angles, only apparent sizes could be obtained.

\section{Cloud point measurements}

The cloud points of the polymers were measured both for the diblock copolymers and for their constituting homopolymeric blocks (PDMS and POEGMA). Commercial PDMS-OH was used for the experiments 
with this block. The synthesis of the POEGMA homopolymer was achieved in conditions similar to those described for the PDMS ${ }_{13}-b$-POEGMA ${ }_{x}$ diblock copolymers except that CTA-COOH was used as chain transfer agent instead of PDMS-CTA with a $[\mathrm{OEGMA}]_{0}:[\mathrm{CTA}-\mathrm{COOH}]_{0}:[\mathrm{AIBN}]_{0}$ molar ratio of 40:1:0.2 and with a final conversion of $56 \%$. In $\mathrm{scCO}_{2}$, the cloud point was measured at $40^{\circ} \mathrm{C}$ as a function of $\mathrm{P}$, whereas in water it was measured as a function of $\mathrm{T}$ for fixed $\mathrm{P}$ values.

Cloud point pressure of the homopolymers and of the diblock copolymers in $\mathrm{scCO}_{2}$

The cloud point pressure in $\mathrm{scCO}_{2}$ was measured both for the diblock copolymers and for their constituting homopolymeric blocks according to Wang and al. ${ }^{30}$ using a high-pressure phase equilibrium apparatus (Separex, France). This high-pressure unit was composed of a variable volume view cell equipped with three sapphire windows and a mechanical stirrer with a pitched blade turbine. The temperature of the cell was maintained at $40^{\circ} \mathrm{C}$ using a water bath. Phase transitions were recorded with a USB camera. In a typical experiment, $100 \mathrm{mg}$ of the tested polymer was transferred into the high-pressure visualization cell. The cell was then sealed and filled with $20 \mathrm{~mL}$ of $\mathrm{CO}_{2}$, leading to $0.5 \%$ (weight/volume, w/v) of polymer in the cell. Finally, the cell was pressurized at 300 bar using a membrane pump (Separex, France). The complete dissolution of the polymer in $\mathrm{scCO}_{2}$ could be visually observed after $10 \mathrm{~min}$ of mechanical stirring. Then, a video was recorded while the pressure inside the cell was slowly reduced at $20 \mathrm{bar} / \mathrm{min}$ using a syringe pump (260D P2 ISCO, USA) connected to the observation cell. The video was then post-treated by ImageJ and the grey intensity was calculated in order to determine the cloud point corresponding to the phase separation of the polymer from $\mathrm{CO}_{2}$. The image grey intensity was calculated from the red $(\mathrm{R})$, green $(\mathrm{G})$ and blue $(\mathrm{B})$ components as $(R+B+G) / 3$ (see SI section 4 , figure S5). The measurements were repeated three times to test their reproducibility.

\section{Cloud point temperature of the polymers in water}

The cloud point temperatures of the POEGMA and PDMS homopolymers were studied in water saturated with $\mathrm{CO}_{2}$ at 1 bar and 250 bar. The high-pressure phase equilibrium apparatus (Separex, France), described above, was filled with $20 \mathrm{~mL}$ of aqueous polymer solution $(1.0 \% \mathrm{w} / \mathrm{v})$. Saturation of $\mathrm{CO}_{2}$ in water was ensured by first raising the temperature to $80^{\circ} \mathrm{C}$ where $\mathrm{CO}_{2}$ was the most soluble in water, stirring for $5 \mathrm{~min}$ and then returning to $40^{\circ} \mathrm{C}$. Then the temperature of the cell was raised by $5^{\circ} \mathrm{C}$ steps and the cloud point was determined based on the macroscopic turbidity observed with a USB camera.

PDMS $_{13}-b$-POEGMA ${ }_{x}$ copolymers were soluble in water at room temperature for different concentrations $(0.1 ; 0.5$ and $1 \% \mathrm{w} / \mathrm{v})$. Their cloud point temperatures $\left(\mathrm{T}_{\mathrm{CP}}\right)$ were determined in water at 1 bar from turbidity measurements (see SI, section 4).

\section{Results and discussion}

\section{Synthesis of $P D M S_{13}-b-P O E G M A_{x}$ diblock copolymers \\ 1.1. Synthesis of $P D M S_{13}-C T A$}

Synthesis of the chain transfer agent-functionalized PDMS (PDMS-CTA) was done by esterification of a commercially available PDMS-OH $\left(\right.$ Figure $3, \mathrm{DP}_{\mathrm{n}}=13$, $\mathrm{M}_{\mathrm{n}}=1,180 \mathrm{~g} / \mathrm{mol}$ ) with a carboxy-functional CTA in the presence of DCC and DMAP, see Figure 3. ${ }^{24}$ After optimization (see SI for details, section 1 and table S1), the optimal selected conditions corresponded to a 
PDMS-OH:CTA-COOH:DCC:DMAP molar ratio of 1:1.5:1.5:0.15. The reaction was conducted overnight in dichloromethane at room temperature. After purification, the polymer was characterized by ${ }^{1} \mathrm{H}$ NMR in $\mathrm{DMSO}^{-} \mathrm{d}_{6}$, revealing the quantitative transformation of the terminal hydroxy functions of PDMS-OH into CTA functions (Figure 3). Indeed, proton $\mathrm{H}_{\mathrm{c}}$ shifted from $3.75 \mathrm{ppm}$ in PDMS-OH to $4.3 \mathrm{ppm}$ in PDMS-CTA (Figure $3 b$ ), whereas proton $\mathrm{H}_{\mathrm{b}}$ shifted from 3.57 to $3.67 \mathrm{ppm}$. No proton characteristic of PDMS-OH could be found in either the raw (data not shown) or purified PDMS-CTA, confirming full conversion.
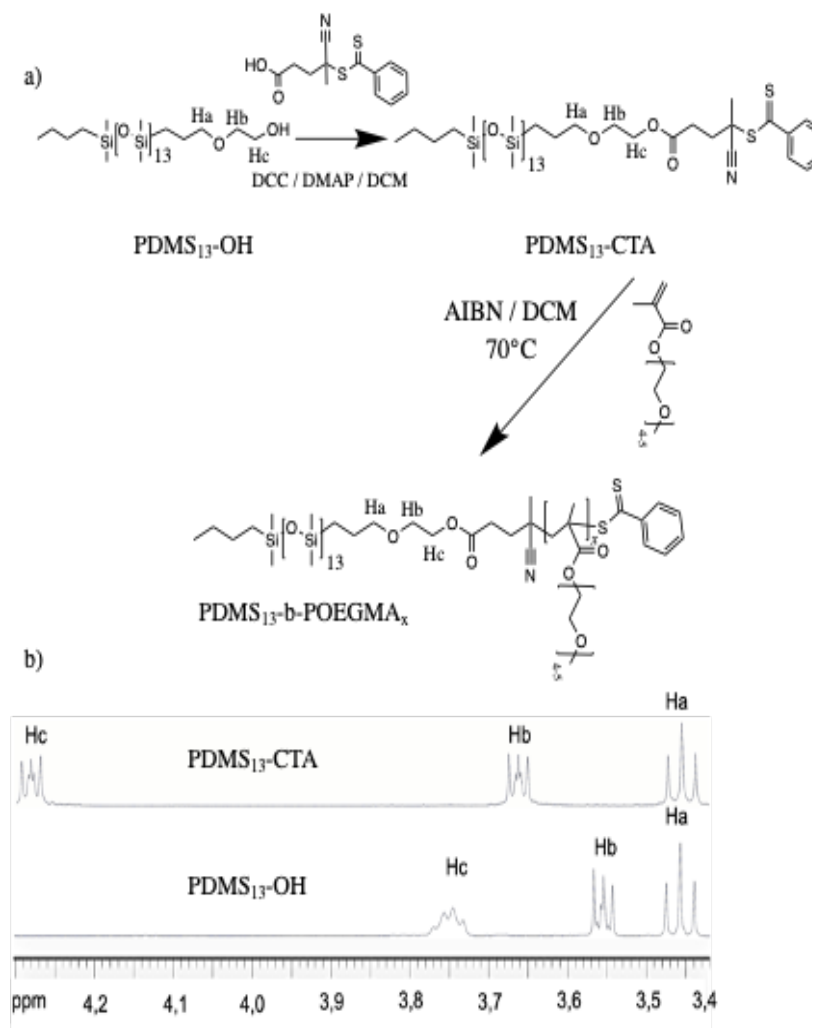

Figure 3. a) Synthetic scheme for the preparation of the PDMS-CTA macro-RAFT agent and of the PDMS- $b$ POEGMA diblock copolymers; b) ${ }^{1} \mathrm{H}$ NMR of the PDMS-CTA and the reference PDMS-OH in the 3.4$4.4 \mathrm{ppm}$ region.

\subsection{Polymerization of OEGMA from PDMS-CTA}

In order to obtain the targeted $\mathrm{PDMS}_{13}-b-\mathrm{POEGMA}_{x}$ diblock copolymers, polymerization of OEGMA was carried out at $70^{\circ} \mathrm{C}$ in toluene $(50: 50$ w:w monomer:toluene ratio) using the PDMS-CTA macroRAFT agent and AIBN as initiator (Figure 3a). Three different degrees of polymerization of the POEGMA block ( $x=16,31$ or 46 ) were successfully obtained by varying both the final conversion and the initial OEGMA: PDMS-CTA molar ratio, see Table 1. Polymerizations were always stopped below $60 \%$ conversion to limit irreversible transfer and termination reactions. Up to the final conversion, $\ln \left([\mathrm{M}]_{0} /[\mathrm{M}]\right)$ evolved linearly with time implying a constant radical concentration; except for an initial inhibition period of 10 to $35 \mathrm{~min}$. 
a)

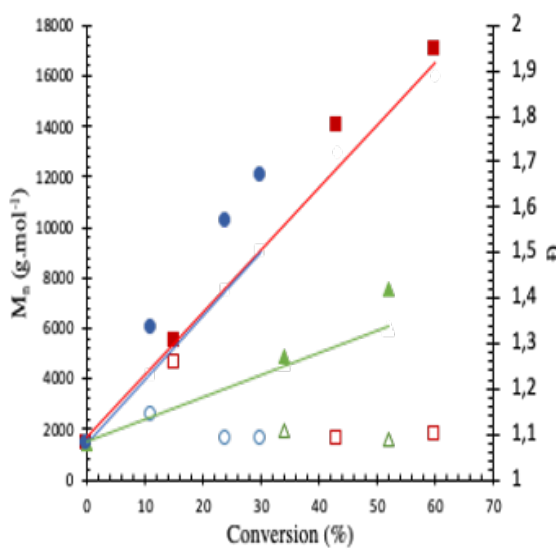

b)

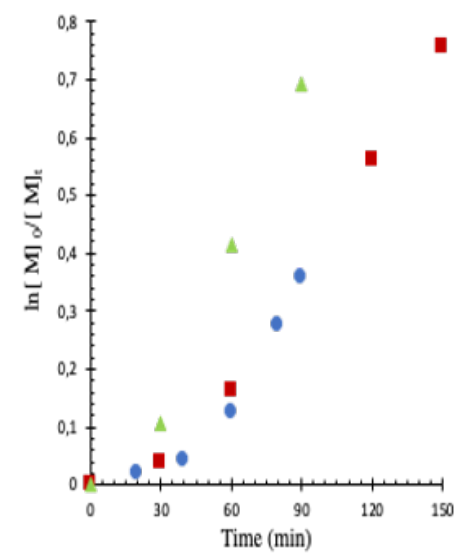

Figure 4. a) Evolution of $\mathrm{M}_{\mathrm{n}}$ (full symbols) and $Đ$ (empty symbols) with conversion during the synthesis of PDMS ${ }_{13}-$ $b$-POEGMA $x$ diblock copolymers $(x=16 \triangle$ and $\triangle, x=31 \bullet$ and $\bigcirc x=46 \square$ and $\square)$. The straight lines correspond to the theoretical evolution of $\mathrm{M}_{\mathrm{n}}=\mathrm{M}_{\mathrm{PDMS}-\mathrm{CTA}}+[\mathrm{OEGMA}]_{0} \times$ conversion $\times \mathrm{M}_{\mathrm{OEGMA}} /\left(\mathrm{f} \times[\mathrm{PDMS}-\mathrm{CTA}]_{0}\right)$ (see Table 1 for conditions, with $\mathrm{M}_{\mathrm{PDMS}-\mathrm{CTA}}=1460 \mathrm{~g} / \mathrm{mol}$ and $\left.\mathrm{M}_{\mathrm{OEGMA}}=300 \mathrm{~g} / \mathrm{mol}\right)$. b) Evolution of $\ln \left([\mathrm{M}]_{0} /[\mathrm{M}]_{\mathrm{t}}\right)$ as a function of time.

The linear evolution of the number average molecular weights $\left(\mathrm{M}_{\mathrm{n}}\right)$ of the diblock copolymers and the decrease of their dispersity $(Đ)$ with conversion indicate a good control of the polymerization of the POEGMA blocks (Figure 4). Additionally, Figure 5 shows that the chromatograms of the macro-RAFT agents shifted to higher molecular weights upon polymerization, confirming the formation of diblock copolymers. However, UV detection revealed that part of the macroCTA was not converted into a diblock copolymer (Figure 5a), resulting in higher molecular weights of the POEGMA blocks than initially targeted (Table 1). Pure diblock copolymers could be obtained after removing unreacted PDMS-CTA by selective precipitation in pentane/diethyl ether $(80 / 20 \mathrm{v} / \mathrm{v})$, see Figure $5 \mathrm{~b}$. Considering the conversion and percentage of PDMSCTA that effectively reacted (see Table 1 and Figure 4a), the experimental molecular weights were consistent within experimental incertitude with the initial [OEGMA]/[CTA] ratio and conversion. In the end, three PDMS $_{13}-b$-POEGMA $x$ with $x=16,31$ and 46 were obtained. The synthesis of a fourth polymer with a very short POEGMA block $(x \sim 5)$ was also attempted. However, the same problem of efficiency of the PDMSCTA block was observed and the POEGMA block was too short for further selective purification (see SI, section 3 for details). 

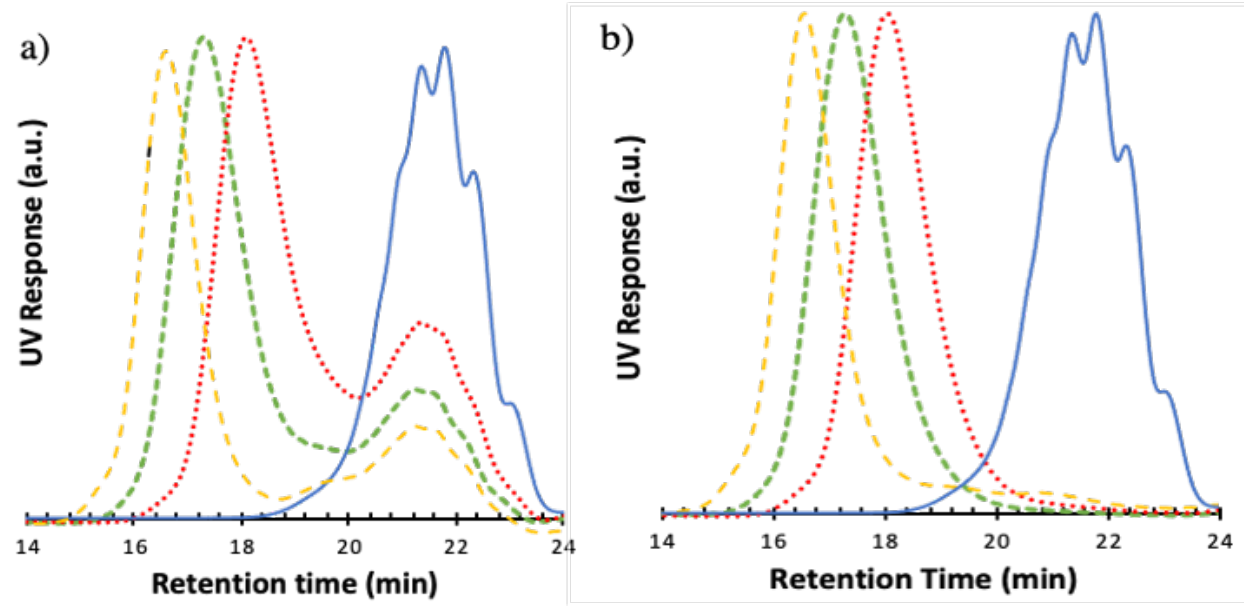

Figure 5. Size exclusion chromatograms of the macroCTA PDMS ${ }_{13}-\mathrm{CTA},(-)$ and of the $\mathrm{PDMS}_{13}-b-\mathrm{POEGMA}_{x}$ diblocks, $\mathrm{DP}_{\mathrm{n}}=16(-\cdots), \mathrm{DP}_{\mathrm{n}}=31(--), \mathrm{DP}_{\mathrm{n}}=46(--)$. a) Before and b) after purification by selective precipitation in pentane/diethyl ether $(80 / 20 \mathrm{v} / \mathrm{v})$. UV detection was used here to detect residual PDMS-CTA.

\section{Effect of PDMS ${ }_{13}-b-P O E G M A_{x}$ on $\gamma$ and emulsion} stability

\subsection{Water-scCO $\mathrm{CO}_{2}$ interfacial tension $(\gamma)$}

$\gamma$ was measured using a pendant-drop tensiometer at various polymer concentrations in the aqueous phase and different temperatures and pressures. The shape of the water droplet stabilized within two minutes and all measurements were performed at pseudo-equilibrium (see experimental section). For the experiments conducted in the presence of polymer, it was verified for the three polymers at 250 bar and $40^{\circ} \mathrm{C}$ that dissolving the polymer initially in the $\mathrm{scCO}_{2}$ or in the water phase did not change the final value of $\gamma$.

First, the effect of the polymer concentration was investigated at $40^{\circ} \mathrm{C}$ and $250 \mathrm{bar}$. The $\gamma$ value of 24 $\mathrm{mN} / \mathrm{m}$ obtained without polymer (Table 2) was in accordance with the values in the literature under the same conditions of $\mathrm{T}$ and $\mathrm{P}$ after an equilibration time of few minutes. ${ }^{32}$ Moreover, the results presented in Table 2 show that the PDMS $_{13}-b$-POEGMA ${ }_{x}$ decrease $\gamma$ below $5 \mathrm{mN} / \mathrm{m}$ with polymer concentrations ranging from 0.1 to $1 \% \mathrm{w} / \mathrm{v}$ in water.

Table 2. $\gamma$ in $\mathrm{mN} / \mathrm{m}$ as a function of the concentrations of $\mathrm{PDMS}_{13}-b$-POEGMA ${ }_{x}(\mathrm{C})$ at $40^{\circ} \mathrm{C}, 250$ bar and for different $x$ values.

\begin{tabular}{lcccc}
\hline & $\boldsymbol{x}=\mathbf{1 6}$ & $\boldsymbol{x}=\mathbf{3 1}$ & $\boldsymbol{x}=\mathbf{4 6}$ & $\begin{array}{l}\text { Without } \\
\text { polymer }\end{array}$ \\
\hline $\mathbf{C}=\mathbf{0 . 1} \% \mathrm{w} / \mathrm{v}$ & 2.3 & 2.0 & 3.5 & \\
$\mathbf{C}=\mathbf{0 . 5} \% \mathrm{w} / \mathrm{v}$ & 2.0 & 1.6 & 4.0 & 24.4 \\
$\mathbf{C = 1 . 0} \% \mathrm{w} / \mathrm{v}$ & 1.5 & 1.2 & 2.2 & \\
\hline
\end{tabular}

Note: Three measurements on three different droplets were conducted for each condition with a maximum variation of $10 \%$ around the average given in this table (all values can be found in Table S2).

This very effective reduction of $\gamma$ could be attributed to the selective affinity of each block for their respective phase. Furthermore, it is worth mentioning that $0.1 \%$ w/v polymer is sufficient to considerably reduce the surface tension whatever the degree of polymerization of the POEGMA block $(x)$. Increasing the concentration 
of the polymer, even by a factor of 10 , contributed only to a modest additional reduction of the interfacial tension. This indicates that with a low amount of polymer, the water- $\mathrm{scCO}_{2}$ interface is already almost saturated. Therefore, the critical micellar concentration (CMC) of the polymer is probably below $0.1 \% \mathrm{w} / \mathrm{v}$ under these conditions.

We have considered the highest concentration (1\% $\mathrm{w} / \mathrm{v})$ in the following experiments where the effect of $\mathrm{P}$ and $\mathrm{T}$ was investigated (Table 3 ).

Table 3. Values of $\gamma$ in $\mathrm{mN} / \mathrm{m}$ as a function of $\mathrm{P}$, at $40^{\circ} \mathrm{C}$, without polymer or with $1 \% \mathrm{w} / \mathrm{v}$ of $\mathrm{PDMS}_{13}-b$ POEGMA $_{x}$ in the aqueous phase for various $x$.

\begin{tabular}{lcccc}
\hline & $\boldsymbol{x}=\mathbf{1 6}$ & $\boldsymbol{x}=\mathbf{3 1}$ & $\boldsymbol{x}=\mathbf{4 6}$ & $\begin{array}{l}\text { Without } \\
\text { polymer }\end{array}$ \\
\hline $\mathrm{P}=100$ bar & 4.0 & 6.2 & 9.5 & 33.5 \\
$\mathrm{P}=150$ bar & 2.3 & 2.4 & 6.9 & 28.3 \\
$\mathrm{P}=200$ bar & 1.8 & 1.7 & 4.6 & 26.2 \\
$\mathrm{P}=250$ bar & 1.5 & 1.2 & 2.2 & 24.4 \\
\hline
\end{tabular}

Note: Three measurements on three different droplets were conducted for each condition with a maximum variation of $10 \%$ around the average given in this table (all values can be found in Table S3).

The $\gamma$ values measured at different pressures without polymer (Table 3) are in accordance with the literature. In fact, $\gamma$ decreases almost linearly but slightly with pressure (Figure 6); which is explained by the decrease of the density difference between water and $\mathrm{scCO}_{2}{ }^{11,32}$ The results show that an increase of $\mathrm{P}$ induces a slight decrease of $\gamma$ both with and without polymer (Table 3). This will be described hereafter considering the effect of temperature as well. The effect of $\mathrm{P}$ on $\gamma$ is stronger for higher $x$ values. A significant decrease of $\gamma$ is observed with the decrease of $x$ at 100 bar, whereas this effect progressively vanishes by increasing the pressure.

Figure 6 compares the effect of pressure on $\gamma$ for $\mathrm{PDMS}_{13}-b$-POEGMA 46 at either 40 or $80^{\circ} \mathrm{C}$. In the absence of polymer, the pressure dependence of $\gamma$ is similar for the two temperatures although $\gamma$ increases slightly when the temperature increases, as already observed in the litterature..$^{32}$ On the contrary, there was a drastic difference between these two temperatures in the presence of $\mathrm{PDMS}_{13}-b$-POEGMA 46 . At $40^{\circ} \mathrm{C}$, the pressure dependences of $\gamma$ with and without polymer are similar. However, the interfacial tension is strongly reduced in the presence of polymer; suggesting a significant but invariant surface activity of the polymer with the pressure at $40^{\circ} \mathrm{C}$. At $80^{\circ} \mathrm{C}, \mathrm{PDMS}_{13}-b$ POEGMA $_{46}$ is not able to reduce $\gamma$ at all at 100 bar, leading to a value close to that of the neat water- $\mathrm{ScCO}_{2}$ interface. Remarkably, $\gamma$ decreases strongly (compared to the case without polymer) with increasing pressure at $80^{\circ} \mathrm{C}$, suggesting an increase of the surface activity of the polymer with the pressure. The polymer is however far less surface active at $80^{\circ} \mathrm{C}$ than at $40^{\circ} \mathrm{C}$, even at 250 bar. These observations are confirmed by representing the evolution of the surface pressure $\pi$ $\left(\mathrm{N} / \mathrm{m}^{2}\right.$ ) (which represents the difference between $\gamma$ without or with polymer respectively) as a function of the $\mathrm{CO}_{2}$ density (see SI, Figure S7 for details) as already done for other systems in the literature. ${ }^{33}$

The behavior of $\mathrm{PDMS}_{13}-b-\mathrm{POEGMA}_{46}$ at $80^{\circ} \mathrm{C}$ can be explained in view of the HCB concept. Indeed, with a nonionic copolymer such as the $\operatorname{PDMS}_{13}-b$ POEGMA 46 , the increase of the $\mathrm{CO}_{2}$ density caused by the increase of pressure induced an increase of the interaction energy between $\mathrm{CO}_{2}$ and the $\mathrm{CO}_{2}$-philic PDMS block (noted $A_{\mathrm{TC}}$ in Eq. 1). Considering the large weight fraction of the POEGMA block (Table 1), we 
assume that $\mathrm{PDMS}_{13}-b$-POEGMA 46 has a hydrophilic tendency $(\mathrm{HCB}>1)$. As a consequence, an increase of $A_{\mathrm{TC}}$ with the pressure can be correlated with a better partition of the polymer at the water- $\mathrm{scCO}_{2}$ interface and thus a decrease of $\gamma$ (right part of the "v-shape" on Figure 1), which is in agreement with our results.

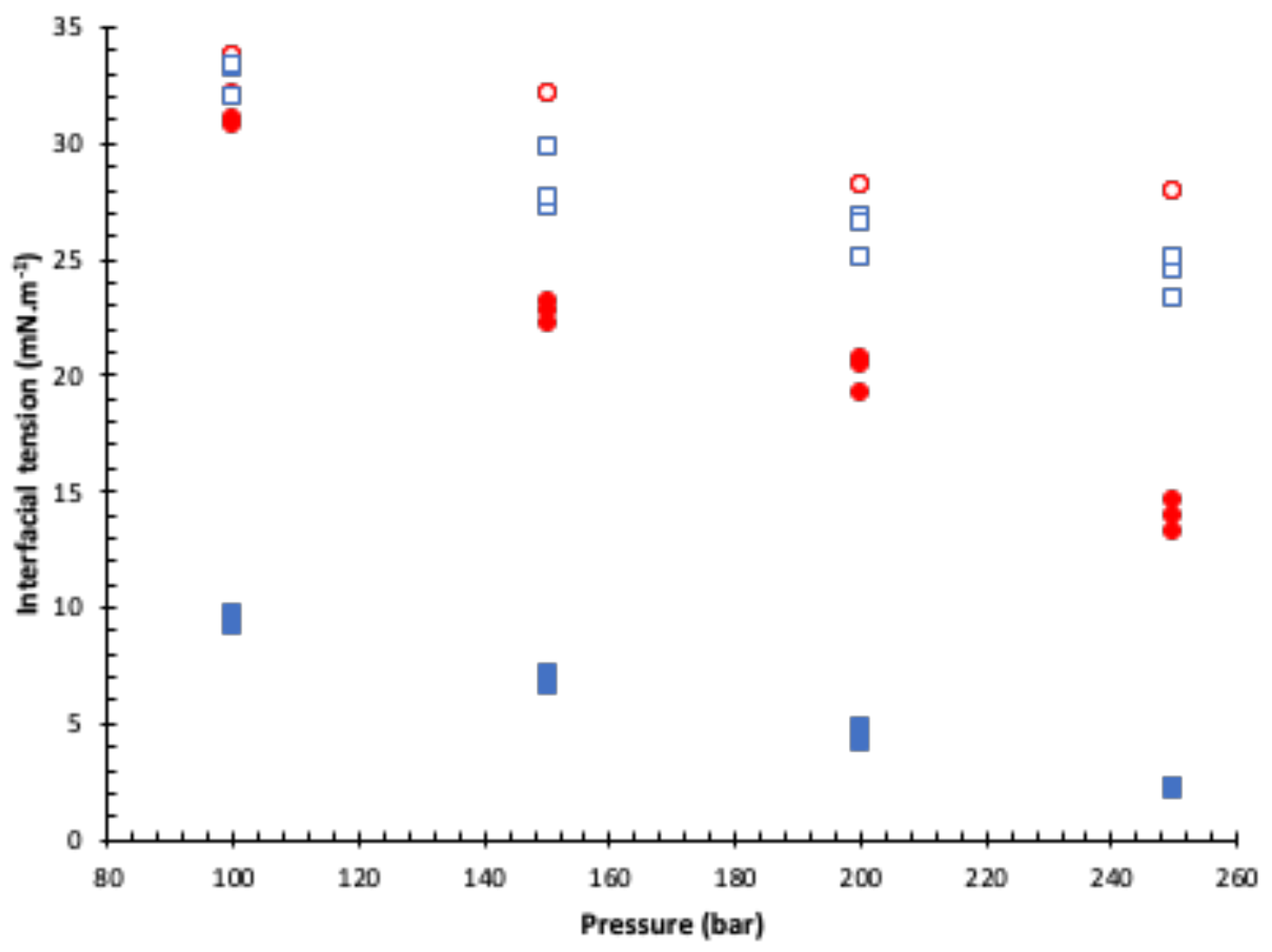

Figure 6. Average interfacial tension as a function of the pressure at different temperatures, $40^{\circ} \mathrm{C}(\square, \square)$ and $80^{\circ} \mathrm{C}$ ( ,0) with $1 \% \mathrm{w} / \mathrm{v} \mathrm{PDMS}_{13}-b$-POEGMA 46 (full symbols) and without polymer (empty symbols). The three measurements performed for each condition are represented on the figure to give an idea of the reproducibility.

To understand more clearly the overall behaviour of the polymer at the interface depending on $P$ and $T$, the solubility of the PDMS and POEGMA homopolymers in each phase was investigated by cloud point measurements. The PDMS block was shown to be insoluble in water at $1 \% \mathrm{w} / \mathrm{v}$ no matter $T$ and $P$. In $\mathrm{scCO}_{2}$ at $40^{\circ} \mathrm{C}$ and at $0.5 \% \mathrm{w} / \mathrm{v}$, it became soluble for $P \geq 120$ bar. The POEGMA block at $0.5 \% \mathrm{w} / \mathrm{v}$ was insoluble in $\mathrm{scCO}_{2}$ at $40^{\circ} \mathrm{C}$ up to 300 bar. In water (saturated with $\mathrm{CO}_{2}$ ) at $0.5 \% \mathrm{w} / \mathrm{v}$, it was soluble up to $75^{\circ} \mathrm{C}$ at $1 \mathrm{bar}$ and only up to $60^{\circ} \mathrm{C}$ at 250 bar. These latter values are in agreement with the cloud point temperature $\left(65^{\circ} \mathrm{C}\right)$ reported for POEGMA in pure water at $1 \mathrm{bar} ;{ }^{34}$ but moreover they showed that the presence of $\mathrm{scCO}_{2}$ in the water phase decreases the solubility of POEGMA. The solubility of the diblock copolymers was also investigated in both phases (see section 4 in the $\mathrm{SI}$ ). In $\mathrm{scCO}_{2}$, at $40^{\circ} \mathrm{C}$ and $0.5 \% \mathrm{w} / \mathrm{v}$, the PDMS $_{13}-b-$ POEGMA $_{x}$ became soluble above $150 \pm$ $8,180 \pm 15$ and $210 \pm 10$ bar for respectively $x=16,31$ and 46 and were not soluble below. In water at 1 bar (from 0.1 to $1 \% \mathrm{w} / \mathrm{v}$ with no significant effect of the polymer concentration), the $\mathrm{PDMS}_{13}-b$-POEGMA $x$ were soluble below $\sim 56^{\circ} \mathrm{C}$ (a variation of $\sim 2^{\circ} \mathrm{C}$ was 
observed between the different $x$ values, see section 4 in SI) and became insoluble above.

These solubility tests explain the surface activity of the PDMS $_{13}-b$-POEGMA $x$ as a function of $P$ and $T$ as summarized in Figure 7 . At $40^{\circ} \mathrm{C}$ and $250 \mathrm{bar}$, the POEGMA block is highly soluble in the water phase, whereas the PDMS block is highly soluble in the $\mathrm{scCO}_{2}$ phase. The $\mathrm{PDMS}_{13}-b$-POEGMA ${ }_{x}$ diblocks therefore go to the interface and efficiently reduce $\gamma$. On the contrary, at $80^{\circ} \mathrm{C}$ and 100 bar, both blocks are neither soluble in $\mathrm{scCO}_{2}$ nor in water, so the polymer precipitate and cannot go to the interface to reduce $\gamma$, as observed for $\mathrm{PDMS}_{13}-b$-POEGMA 46 . The two other conditions depicted on Figure 7 are intermediate situations. At $40^{\circ} \mathrm{C}$ and 100 bar, the POEGMA block is still highly soluble in the water phase, but the PDMS block is not soluble in the $\mathrm{scCO}_{2}$ phase. As the interfacial tension is still efficiently decreased under these conditions (albeit not as well as at higher pressures), the polymer still goes to the interface; probably in the form of unimers with a partly collapsed PDMS block. We stress that for the interfacial tension measurements, the diblock copolymer is initially dispersed in the water phase where it is macroscopically soluble (see section 4 of the
SI). Moreover, for each interfacial measurement, a pendant drop is created only after $T$ and $P$ have reached an equilibrium. The fact that $\gamma$ is still reduced in these conditions $\left(40^{\circ} \mathrm{C}, 100 \mathrm{bar}\right)$ in the presence of polymer implies that the latter does move to the interface from the water phase in spite of the low affinity of the PDMS block for the $\mathrm{scCO}_{2}$ phase. Similarly, at $80^{\circ} \mathrm{C}$ and 250 bar, the PDMS block is still highly soluble in the $\mathrm{scCO}_{2}$ phase, but the POEGMA block is no more soluble in the water phase. In these conditions, the diblock copolymer is not soluble in the water phase (see section 4 of the SI). It follows that when the droplet is formed starting with the polymer inside the aqueous phase, the polymer is phase separated. It may therefore be argued that the reduction of $\gamma$ in these conditions results from the presence of ill-defined aggregates of $\mathrm{PDMS}_{13}-b$-POEGMA 46 at the interface. However, a control experiment conducted by initially dissolving the polymer in the $\mathrm{scCO}_{2}$ phase where it is macroscopically soluble (see section 4) led to the same reduction of $\gamma$. As a conclusion, the observed reduction of $\gamma$ at $80^{\circ} \mathrm{C}$ and 250 bar is probably due to the presence of unimers with a partly collapsed POEGMA block at the interface (Figure 7). 


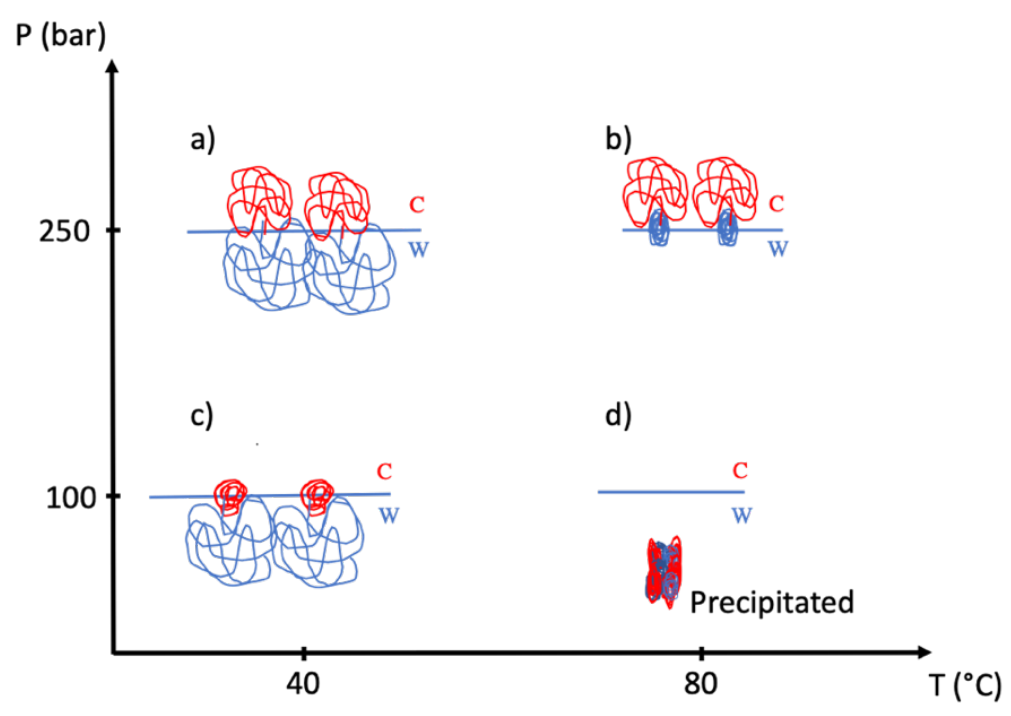

Figure 7. Schematic illustration of the organization of $\mathrm{PDMS}_{13}-b$-POEGMA 46 at the $\mathrm{scCO}_{2}(\mathrm{C})$-Water (W) interface for different pressures and temperatures indicated in the figure, explaining the impact of these parameters on the variation of $\gamma$, see text: a) unimers with their two blocks well-swollen in their respective phase; b) unimers with a partly collapsed POEGMA block; c) unimers with a partly collapsed PDMS block; d) precipitated polymer which does not go to the interface.

\subsection{Stabilization of emulsions at $40^{\circ} \mathrm{C}$}

In view of their efficiency to reduce $\gamma$, the diblock copolymers were tested as stabilizers for water- $\mathrm{scCO}_{2}$ emulsions. $50 / 50$ water $/ \mathrm{scCO}_{2}$ volume ratios were mechanically emulsified in a pressurized batch reactor in the presence of $0.5 \% \mathrm{w} / \mathrm{v}$ of polymer with respect to the total volume. At $40^{\circ} \mathrm{C}$ and for pressures ranging from 100 to $250 \mathrm{bar}$, white opaque emulsions were obtained right after mixing in all cases (Figure 8b). After less than $5 \mathrm{~min}$, creaming was observed leading to the appearance of a white opaque emulsion above and a slightly turbid (for $\mathrm{PDMS}_{13}-b$-POEGMA ${ }_{46}$ at $P=100$ 200 bar, Figure 8d) or nearly transparent (for all other conditions, Figure 8c) aqueous phase below. In spite of creaming, the upper phase remained white and opaque for at least $15 \mathrm{~min}$ (some samples were monitored for more than $30 \mathrm{~min}$ and a white opaque upper phase was still there); revealing that the copolymers limited the coalescence of droplets to some extent, while the coalescence occurred within seconds without polymer. It was technically not possible to determine which phase was dispersed in the other. However, the fact that the amphiphilic copolymers had a predominantly hydrophilic character due to the weight fraction of the POEGMA block (see Table 1) suggests that $\mathrm{scCO}_{2}$ in water emulsions were formed according to Bancroft's rule. ${ }^{5,26}$ This hypothesis is somewhat supported by the fact that the emulsions creamed (water in $\mathrm{scCO}_{2}$ emulsions would have sedimented).

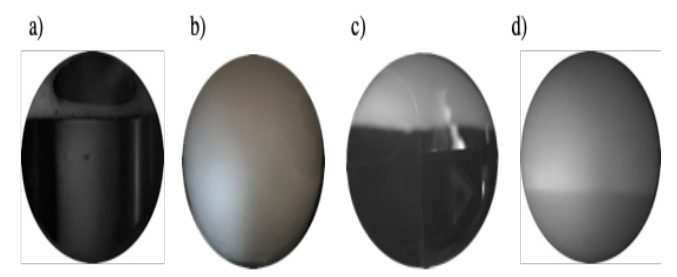

Figure 8. Typical pictures of the water $/ \mathrm{scCO}_{2} / \mathrm{PDMS}_{13^{-}}$ $b$-POEGMA ${ }_{x}$ mixtures in different states: a) unmixed polymer aqueous solution (bottom phase) and $\mathrm{scCO}_{2}$ phase (top phase), b) completely emulsified system just 
after mixing, c) partially creamed emulsion (top phase) with a clear aqueous phase below - observed for all conditions except $\mathrm{PDMS}_{13}-b$-POEGMA 46 at $P=100$ 200 bar, d) partially creamed emulsion (top phase) with a slightly turbid aqueous phase below - observed for PDMS $_{13}-b$-POEGMA 46 at $P=100-200$ bar only. The pictures were taken under natural light.

The aqueous polymer phase was first investigated before emulsification. Light scattering and cryogenic Transmission Electron Microscopy (cryoTEM) revealed the presence of small spherical micelles significantly scattering light at 1 bar and room temperature (see SI, section 6). When the light scattering experiments were conducted under pressure through the visualization window of the home-made device, a small amount of larger aggregates were observed. The latter could not be avoided in the somewhat degraded conditions of cleanliness of the experiments in the home-made device compared to the experiments ca rried out at room temperature and 1 bar where all solutions were thoroughly filtered into perfectly clean and dust-free vials (see SI, section 6). The presence of micelles at this concentration in the aqueous phase is consistent with the interfacial tension measurements discussed above which suggest that a concentration of $1 \% \mathrm{w} / \mathrm{v}$ is well above the CMC of the polymers. The formation of micelles is also consistent with the solubility tests on the homopolymers which indicate that, at $40^{\circ} \mathrm{C}$ and $100-250$ bar, water is a selective solvent for POEGMA.

After emulsification and creaming, most bottom phases (except PDMS $_{13}-b-$ POEGMA $_{46}$ at $P=100-200$ bar) were sufficiently transparent to be investigated by light scattering too. These aqueous phases scattered much less light than the non-emulsified initial aqueous polymer phases (Table 4). For PDMS ${ }_{13}-b$-POEGMA 16 , DLS revealed a strong increase of the relaxation time after emulsification and creaming, suggesting the presence of very large scatterers which should have caused a strong increase of scattered light intensity and turbidity if their amount had been sufficient (see SI, Figure S9). For this polymer, the decrease of the scattered intensity in the aqueous phase after creaming could therefore only be attributed to a much lower polymer concentration in this phase than before emulsification. In other words, a significant quantity of the diblock copolymer was present in the upper emulsion and stabilized it. Moreover, both the decrease of scattered light intensity and the absence of significant turbidity (Figure 8c) of the creamed aqueous phase implied that the quantity of very large scatterers was actually negligible. We speculate that these large scatterers corresponded to a very small amount of $\mathrm{scCO}_{2}$ droplets which had not yet creamed.

The same conclusion could be drawn for $\mathrm{PDMS}_{13}-b$ POEGMA $_{31}$ at 100 and 250 bar (see Table 4 and Figure S9). For PDMS PM-POEGMA $_{13}$ at 150 and 200 bar and for $\mathrm{PDMS}_{13}-b$-POEGMA 46 at 250 bar, DLS revealed a small decrease of the size of the scatterers (see Figure S9) which could also account for the lower scattered intensity. This means that the relative polymer concentration in these conditions is probably higher than the relative scattered intensity indicated in Table 4. Still, we hypothesize that the polymer concentration was also lower in this phase after emulsification and creaming considering 1 ) the trend observed in the other conditions and 2) the fact that the emulsion is stabilized only in the presence of polymer. We note that the relative decrease of scattered intensity in the aqueous phase after emulsification and creaming was much less pronounced for increasing $x$. This result seems consistent with the fact that the $\mathrm{PDMS}_{13}-b$-POEGMA have a HCB $>1$ and therefore a stronger affinity for the water than for the $\mathrm{scCO}_{2}$ phase: decreasing $x$ leads to a 
more balanced affinity of the diblock copolymer for both phases and therefore to its migration to the emulsion rather than to the excess water phase.

Table 4. Intensity of the scattered light in the aqueous phase after emulsification and creaming expressed in percent relative to the initial scattered intensity of the $\mathrm{PDMS}_{13}-b$-POEGMA $\mathrm{A}_{\mathrm{x}}$ diblock copolymer aqueous solution at $1 \% \mathrm{w} / \mathrm{v}\left(100 \mathrm{bar}, 40^{\circ} \mathrm{C}\right)$ before any emulsification.

\begin{tabular}{lccc}
\hline & $\boldsymbol{x}=\mathbf{1 6}$ & $\boldsymbol{x}=\mathbf{3 1}$ & $\boldsymbol{x}=\mathbf{4 6}$ \\
\hline $\mathrm{P}=100$ bar & $0.7 \%$ & $20 \%$ & n.a. \\
$\mathrm{P}=150$ bar & $3 \%$ & $10 \% *$ & n.a. \\
$\mathrm{P}=200$ bar & $6 \%$ & $10 \% *$ & n.a. \\
$\mathrm{P}=250$ bar & $5 \%$ & $10 \%$ & $52 \%{ }^{*}$ \\
\hline
\end{tabular}

n.a. Not applicable because these samples were significantly turbid (see Figure 8d), implying a strong influence of multiple scattering on the results. The turbidity was attributed to the presence of a significant amount of relatively large $\mathrm{scCO}_{2}$ droplets which had not yet creamed.

* For these samples, DLS revealed that the size of the scatterers was slightly smaller than before emulsification and creaming so that the decrease of scattered light intensity could be attributed either to a decrease of polymer concentration, or to a decrease of the size of the scatterers or to a combination of both. This means that the relative polymer concentration in these conditions is probably higher than the value of the relative scattered intensity.

\subsection{Thermo-responsive emulsions}

Finally, the impact of the thermo-sensitive behavior of the POEGMA block on the stabilization of emulsions was tested by emulsifying a $50 / 50$ water/ $/ \mathrm{scO}_{2}$ mixture in the presence of $0.5 \% \mathrm{w} / \mathrm{v}$ of $\mathrm{PDMS}_{13}-b$-POEGMA 46 . At 100 bar, a thermo-reversible emulsification was observed. Indeed, $\mathrm{scCO}_{2}$ and water formed a stable emulsion at $40^{\circ} \mathrm{C}$ which destabilized within few seconds into two transparent phases (Figure 8a) by increasing the temperature to $80^{\circ} \mathrm{C}$. Attempts to re-emulsify the two phases at 100 bar and $80^{\circ} \mathrm{C}$ were not successful, whereas decreasing again the temperature to $40^{\circ} \mathrm{C}$ and stirring for a few minutes afforded again an emulsion. This result was in perfect agreement with the understanding of the system depicted on figure 7 : the polymer desorbed and adsorbed reversibly from the interface at 100 bar by increasing or decreasing the temperature.

The same experiment was also conducted at 250 bar. At this pressure, it was not possible to emulsify water and $\mathrm{scCO}_{2}$ at $80^{\circ} \mathrm{C}$. However, if the emulsion was first formed at $250 \mathrm{bar}$ and $40^{\circ} \mathrm{C}$ and then heated up to $80^{\circ} \mathrm{C}$, destabilization did not occur. This could probably be attributed to the fact that the diblock copolymer was not soluble in water at $80^{\circ} \mathrm{C}$ and 250 bar so that long times or strong shearing would have been necessary to bring enough polymer at the interface to emulsify the system. On the contrary, by starting at $40^{\circ} \mathrm{C}$ and 250 bar, the polymer was already at the interface. Raising the temperature to $80^{\circ} \mathrm{C}$ probably caused a collapse of the POEGMA block but did not remove the polymer from the interface (indeed, it still exhibited some surface activity at $80^{\circ} \mathrm{C}$ and 250 bar as shown above, see Figure 6) and did not cause destabilization of the emulsion. It is even possible that the collapsed POEGMA blocks developed attractive interactions at the interface, strengthening the efficiency of the polymer protection 
at the interface due to the sticking of unimers at the interface.

\section{Conclusion}

To develop new potential applications for water- $\mathrm{scCO}_{2}$ emulsification processes, a family of well-defined $\mathrm{PDMS}_{13}-b$-POEGMA $x$ copolymers, with three different POEGMA block sizes, were synthesized by RAFT. This work aimed at characterizing the relationship between the affinity of each block for their respective phase, their ability to decrease $\gamma$ and the consequences on the stability of emulsions in different conditions of $P$ and $T$. Hence, the development of a home-made experimental device (with implemented characterization techniques: direct visualization, DLS and droplet tensiometry) led to the following significant findings. The $\mathrm{PDMS}_{13}-b-$ POEGMA $_{x}$ diblock copolymers were able to reduce $\gamma$ by up to a factor of 20. Their high-performance $(\gamma$ was reduced down to $1.2 \mathrm{mN} / \mathrm{m}$ ) was similar to that of other Pluronics $®$ and Fluorinated copolymers. ${ }^{2}$ These polymers were able to form emulsions for which coalescence was significantly retarded, although creaming could not be suppressed. The thermosensitivity of the copolymers due to the POEGMA block resulted in a strong variation of $\gamma$ with $T$ (in the $40-80^{\circ} \mathrm{C}$ range), which allowed the thermo-reversible stabilization/destabilization of water- $\mathrm{ScCO}_{2}$ emulsions (at 100 bar). This stimuli-responsivness could be useful for various applications such as emulsion polymerization, catalyst recovery, and cosmetics, as recently reviewed by Tang et al. for stimuli-responsive oil/water Pickering emulsions..$^{35,36}$ Moreover, in our laboratory, we aim to develop sustainable water- $\mathrm{scCO}_{2}$ emulsification processes ${ }^{6}$ for which the droplets of the emulsions act as micro- or nanoreactors in which the $\mathrm{CaCO}_{3}$ crystallization is carefully controlled to produce nanostructured and porous particles ${ }^{37}$ used as drug carriers. ${ }^{38,39,40}$ These copolymers could be relevant in this context too.

\section{ASSOCIATED CONTENT}

1. Optimization of the conditions for the synthesis of $\mathrm{PDMS}_{13}-\mathrm{CTA} ; 2$. Efficiency of the $\mathrm{PDMS}_{13}-\mathrm{CTA}$ during the RAFT polymerization; 3. Synthesis and characterization of $\mathrm{PDMS}_{13}-b$-POEGMA $; 4$ Determination of the cloud point pressure in $\mathrm{CO} 2$ and of the cloud point temperature in water; 5. $\gamma$ measurements; 6 . Investigation of the aqueous phase before and after emulsification.

\section{AUTHOR INFORMATION}

\section{Corresponding Authors}

* olivier.colombani@univ-lemans.fr;

brice.calvignac@univ-angers.fr

\section{Author Contributions}

The manuscript was written through contributions of all authors. All authors have given approval to the final version of the manuscript.

\section{Funding Sources}

This work was supported by the Region Pays de Loire (France) in the frame of the SPEED program (PhD grant to P. Legout) and by the French ANR in the frame of the CarboMIC project (ANR-19-CE09-0012-01).

This work was supported by the Region Pays de Loire (France) in the frame of the SPEED program (PhD grant 
to P. Legout) and by the French ANR in the frame of the CarboMIC project (ANR-19-CE09-0012-01). The authors thank Boris Jacquette (IMMM) for characterizations of the copolymers by SEC, Frédérick Niepceron for the cryoTEM experiment, Domitille Lefebvre (MINT, IMMM) for her implication on the $\gamma$ measurements, Teclis-scientific (France) and Top Industrie (Vaux Le Pénil, France) for their implication in the design of the experimental bench and software, Cordouan Technologies for the technical support regarding the particle size analyzer.

\section{REFERENCES}

(1) Bertucco, A.; Vetter, G. High Pressure Process Technology Fundamentals and Applications; 2001 .

(2) Girard, E.; Tassaing, T.; Marty, J.-D.; Destarac, M. Structure-Property Relationships in CO2Philic (Co)Polymers: Phase Behavior, Self-Assembly, and Stabilization of Water/CO2 Emulsions. Chem. Rev. 2016, $116 \quad$ (7), 4125-4169. https://doi.org/10.1021/acs.chemrev.5b00420.

(3) Lee, C. T.; Psathas, P. A.; Johnston, K. P.; deGrazia, J.; Randolph, T. W. Water-in-Carbon Dioxide Emulsions: Formation and Stability. Langmuir 1999, 15 (20), 6781-6791. https://doi.org/10.1021/la9903548.

(4) Johnston, K. P.; Jacobson, G. B.; Ted Lee, C.; Meredith, C.; Da Rocha, S. R. P.; Yates, M. Z.; Degrazia, J.; Randolph, T. W. Microemulsions, Emulsions and Latexes. In Chem. Synth. Using Supercrit. Fluids; 2007; pp 127-146. https://doi.org/10.1002/9783527613687.ch7.

(5) Johnston, K. P.; Rocha, S. R. P. da. Colloids in Supercritical Fluids over the Last 20 Years and Future Directions. J. Supercrit. Fluids 2009, 47 (3), 523-530. https://doi.org/10.1016/j.supflu.2008.10.024.

(6) Beuvier, T.; Calvignac, B.; Delcroix, G. J.-R.; Tran, M. K.; Kodjikian, S.; Delorme, N.; Bardeau, J.-F.; Gibaud, A.; Boury, F. Synthesis of Hollow Vaterite $\mathrm{CaCO} 3$ Microspheres in Supercritical Carbon Dioxide Medium. J. Mater. Chem. 2011, 21 (26), 9757. https://doi.org/10.1039/c1jm10770d.

(7) Harrison, K.; Goveas, J.; Johnston, K. P.; O'Rear, E. A. Water-in-Carbon Dioxide Microemulsions with a Fluorocarbon-Hydrocarbon Hybrid Surfactant. Langmuir 1994, 10 (10), 3536-3541. https://doi.org/10.1021/1a00022a028.

(8) Ryoo, W.; Webber, S. E.; Johnston, K. P. Water-in-Carbon Dioxide Microemulsions with Methylated Branched Hydrocarbon Surfactants. Ind. Eng. Chem. Res. 2003, 42 (25), 6348-6358. https://doi.org/10.1021/ie0300427.

(9) Sagisaka, M.; Narumi, T.; Niwase, M.; Narita, S.; Ohata, A.; James, C.; Yoshizawa, A.; Taffin de Givenchy, E.; Guittard, F.; Alexander, S.; Eastoe, J. Hyperbranched Hydrocarbon Surfactants Give Fluorocarbon-like Low Surface Energies. Langmuir 2014, $30 \quad$ (21), 6057-6063. https://doi.org/10.1021/la501328s.

(10) Sagisaka, M.; Saito, T.; Yoshizawa, A.; Rogers, S. E.; Guittard, F.; Hill, C.; Eastoe, J.; Blesic, M. Water-in-CO2 Microemulsions Stabilized by Fluorinated Cation-Anion Surfactant Pairs. Langmuir 2019, 35 (9), 3445-3454. https://doi.org/10.1021/acs.langmuir.8b03942.

(11) da Rocha, S. R. P.; Harrison, K. L.; Johnston, K. P. Effect of Surfactants on the Interfacial Tension and Emulsion Formation between Water and Carbon Dioxide. Langmuir 1999, 15 (2), 419-428. 
https://doi.org/10.1021/la980844k.

(12) Psathas, P. A.; da Rocha, S. R. P.; Lee, C. T.; Johnston, K. P.; Lim, K. T.; Webber, S. Water-inCarbon Dioxide Emulsions with Poly(Dimethylsiloxane)-Based Block Copolymer Ionomers. Ind. Eng. Chem. Res. 2000, 39 (8), 26552664. https://doi.org/10.1021/ie990779p.

(13) Ryoo, W.; Webber, S. E.; Bonnecaze, R. T.; Johnston, K. P. Long-Ranged Electrostatic Repulsion and Crystallization of Emulsion Droplets in an Ultralow Dielectric Medium Supercritical Carbon Dioxide. Langmuir 2006, 22 (3), 1006-1015. https://doi.org/10.1021/la052298i.

(14) S. Adkins, S.; Gohil, D.; L. Dickson, J.; E. Webber, S.; P. Johnston, K. Water-in-Carbon Dioxide Emulsions Stabilized with Hydrophobic Silica Particles. Physical Chemistry Chemical Physics 2007, 9 (48), 6333-6343. https://doi.org/10.1039/B711195A.

(15) Yang, Y.; Fang, Z.; Chen, X.; Zhang, W.; Xie, Y.; Chen, Y.; Liu, Z.; Yuan, W. An Overview of Pickering Emulsions: Solid-Particle Materials, Classification, Morphology, and Applications. Front. $\begin{array}{llll}\text { Pharmacol. } & \text { 2017, } & 8, & \end{array}$ https://doi.org/10.3389/fphar.2017.00287.

(16) Chevalier, Y.; Bolzinger, M.-A. Emulsions Stabilized with Solid Nanoparticles: Pickering Emulsions. Colloids Surf. A Physicochem. Eng. Asp. 2013, 439 , 23-34.

https://doi.org/10.1016/j.colsurfa.2013.02.054.

(17) Shen, Z.; McHugh, M. A.; Xu, J.; Belardi, J.; Kilic, S.; Mesiano, A.; Bane, S.; Karnikas, C.; Beckman, E.; Enick, R. CO2-Solubility of Oligomers and Polymers That Contain the Carbonyl Group. Polymer 2003, 44 (5), 1491-1498.
https://doi.org/10.1016/S0032-3861(03)00020-X.

(18) Lee, J. J.; Cummings, S. D.; Beckman, E. J.; Enick, R. M.; Burgess, W. A.; Doherty, M. D.; O’Brien, M. J.; Perry, R. J. The Solubility of Low Molecular Weight Poly(Dimethyl Siloxane) in Dense CO2 and Its Use as a CO2-Philic Segment. J. Supercrit. Fluids 2017, 119 , $17-25$. https://doi.org/10.1016/j.supflu.2016.08.003.

(19) Psathas, P. A.; Sander, E. A.; Lee, M. Y.; Lim, K. T.; Johnston, K. P. Mapping the Stability and Curvature of Emulsions of $\mathrm{H}_{2} \mathrm{O}$ and Supercritical CO 2 with Interfacial Tension Measurements. J. Dispersion Sci. Technol. 2002, 23 (1-3), 65-80. https://doi.org/10.1080/01932690208984190.

(20) Psathas, P. A.; Janowiak, M. L.; Garcia-Rubio, L. H.; Johnston, K. P. Formation of Carbon Dioxide in Water Miniemulsions Using the Phase Inversion Temperature Method. Langmuir 2002, 18 (8), 30393046. https://doi.org/10.1021/la015677u.

(21) GRIFFIN, W. C. Calculation of HLB Values of Non-Ionic Surfactants. J. Soc. Cosmet. Chem. 1954, $5,249-256$.

(22) Becher, P. Microemulsions and Related Systems: Formulation, Solvency, and Physical Properties. J. Dispersion Sci. Technol. 1990, 11 (4), 431-432. https://doi.org/10.1080/01932699008943264.

(23) Salager, J. L.; Morgan, J. C.; Schechter, R. S.; Wade, W. H.; Vasquez, E. Optimum Formulation of Surfactant/Water/Oil Systems for Minimum Interfacial Tension or Phase Behavior. J. Soc. Pet. Eng. 1979, 19 (02), 107-115. https://doi.org/10.2118/7054-PA.

(24) Salager, J.-L.; Marquez, N.; Graciaa, A.; Lachaise, J. Partitioning of Ethoxylated Octylphenol 
Surfactants in Microemulsion-Oil-Water Systems: Influence of Temperature and Relation between Partitioning Coefficient and Physicochemical Formulation. Langmuir 2000, 16 (13), 5534-5539. https://doi.org/10.1021/la9905517.

(25) Bao, L.; Fang, S.; Hu, D.; Zong, Y.; Zhao, L.; Yuan, W.; Liu, T. Stabilization of CO2-in-Water Emulsions by Nonfluorinated Surfactants with Enhanced CO2-Philic Tails. J. Supercrit. Fluids 2018, 133 $163-170$.

https://doi.org/10.1016/j.supflu.2017.10.007.

(26) Bancroft, W. D. The Theory of Emulsification, V. J. Phys. Chem. 1913, 17 (6), 501-519. https://doi.org/10.1021/j150141a002.

(27) Poly(Ethylene Glycol) Methyl Ether Methacrylate, Mn: 300 g/Mol, Cas : 447935.

(28) Kurjata, J.; Chojnowski, J.; Yeoh, C.-T.; Rossi, N. A. A.; Holder, S. J. Synthesis of Poly[Dimethylsiloxane-Block-Oligo(Ethylene Glycol) Methyl Ether Methacrylate]: An Amphiphilic Copolymer with a Comb-like Block. Polymer 2004, 45 (18),

6111-6121.

https://doi.org/10.1016/j.polymer.2004.06.062.

(29) Chen, X.; Adkins, S. S.; Nguyen, Q. P.; Sanders, A. W.; Johnston, K. P. Interfacial Tension and the Behavior of Microemulsions and Macroemulsions of Water and Carbon Dioxide with a Branched Hydrocarbon Nonionic Surfactant. J. Supercrit. Fluids 2010, $55 \quad$ (2), 712-723. https://doi.org/10.1016/j.supflu.2010.08.019.

(30) Wang, M.; Harrisson, S.; Destarac, M.; Marty, J.-D. Measuring Cloud Point Pressures by Image Analysis: A Simple and Reproducible Alternative Method to Direct Visual Determination. J. Supercrit. $\begin{array}{llll}\text { Fluids } & \mathbf{2 0 1 9}, & 104572 .\end{array}$ https://doi.org/10.1016/j.supflu.2019.104572.

(31) Duong, T.; Bressy, C.; Margaillan, A. WellDefined Diblock Copolymers of Poly(TertButyldimethylsilyl Methacrylate) and Poly(Dimethylsiloxane) Synthesized by RAFT Polymerization. Polymer 2014, 55, 39-47. https://doi.org/10.1016/j.polymer.2013.11.034.

(32) Georgiadis, A.; Maitland, G.; Trusler, J. P. M.; Bismarck, A. Interfacial Tension Measurements of the $(\mathrm{H} 2 \mathrm{O}+\mathrm{CO} 2)$ System at Elevated Pressures and Temperatures. J. Chem. Eng. Data 2010, 55 (10), 41684175. https://doi.org/10.1021/je100198g.

(33) Adkins, S. S.; Chen, X.; Nguyen, Q. P.; Sanders, A. W.; Johnston, K. P. Effect of Branching on the Interfacial Properties of Nonionic Hydrocarbon Surfactants at the Air-Water and Carbon DioxideWater Interfaces. J. Colloid Interface Sci. 2010, 346 (2), 455-463. https://doi.org/10.1016/j.jcis.2009.12.059.

(34) Lutz, J.-F. Polymerization of Oligo(Ethylene Glycol) (Meth)Acrylates: Toward New Generations of Smart Biocompatible Materials. J. Polym. Sci. A Polym. Chem. 2008, 46 (11), 3459-3470. https://doi.org/10.1002/pola.22706.

(35) Tang, J.; Cao, S.; Wang, J. CO2-Switchable Pickering Emulsions: Efficient and Tunable Interfacial Catalysis for Alcohol Oxidation in Biphasic Systems. Chem. Commun. 2019, 55 (74), 11079-11082. https://doi.org/10.1039/C9CC04947A.

(36) Tang, J.; Quinlan, P. J.; Tam, K. C. StimuliResponsive Pickering Emulsions: Recent Advances and Potential Applications. Soft Matter 2015, 11 (18), 35123529. https://doi.org/10.1039/C5SM00247H. 
(37) Chavez Panduro, E. A.; Beuvier, T.; Fernández Martínez, M.; Hassani, L.; Calvignac, B.; Boury, F.; Gibaud, A. Small-Angle X-Ray Scattering Analysis of Porous Powders of $\mathrm{CaCO}_{3}$. J Appl Crystallogr 2012, 45 (5), 881-889. https://doi.org/10.1107/S0021889812032219.

(38) Tran, M.-K.; Hassani, L. N.; Calvignac, B.; Beuvier, T.; Hindré, F.; Boury, F. Lysozyme Encapsulation within PLGA and $\mathrm{CaCO} 3$ Microparticles Using Supercritical CO2 Medium. J. Supercrit. Fluids 2014, 88 , 142. https://doi.org/10.1016/j.supflu.2014.02.018.
(39) Hassani, L. N.; Hindré, F.; Beuvier, T.; Calvignac, B.; Lautram, N.; Gibaud, A.; Boury, F. Lysozyme Encapsulation into Nanostructured $\mathrm{CaCO} 3$ Microparticles Using a Supercritical CO2 Process and Comparison with the Normal Route. J. Mater. Chem. B 2013, 1 (32), 4011. https://doi.org/10.1039/c3tb20467g.

(40) Zeynep, E. Y.; Antoine, D.; Brice, C.; Frank, B.; Christine, J. Double Hydrophilic Polyphosphoester Containing Copolymers as Efficient Templating Agents for Calcium Carbonate Microparticles. J. Mater. Chem. $\begin{array}{lllll}B & \mathbf{2 0 1 5}, & 3 & \text { (36), } & \text { 7227-7236. }\end{array}$ https://doi.org/10.1039/C5TB00887E. 